\title{
Education sector response to early and unintended pregnancy: A review of country experiences in sub-Saharan Africa
}

\author{
Harriet Birungi \\ Population Council \\ Chi-Chi Undie \\ Population Council \\ Ian MacKenzie \\ Anne Katahoire \\ Francis Obare \\ Population Council
}

See next page for additional authors

Follow this and additional works at: https://knowledgecommons.popcouncil.org/departments_sbsr-rh

Part of the Demography, Population, and Ecology Commons, Education Policy Commons, Family, Life Course, and Society Commons, Gender and Sexuality Commons, International Public Health Commons, Maternal and Child Health Commons, and the Women's Health Commons How does access to this work benefit you? Let us know!

\section{Recommended Citation}

Birungi, Harriet, Chi-Chi Undie, Ian MacKenzie, Anne Katahoire, Francis Obare, and Patricia Machawira. 2015. "Education sector response to early and unintended pregnancy: A review of country experiences in sub-Saharan Africa," STEP UP Research Report. Nairobi: Population Council. 


\section{Authors}

Harriet Birungi, Chi-Chi Undie, Ian MacKenzie, Anne Katahoire, Francis Obare, and Patricia Machawira 


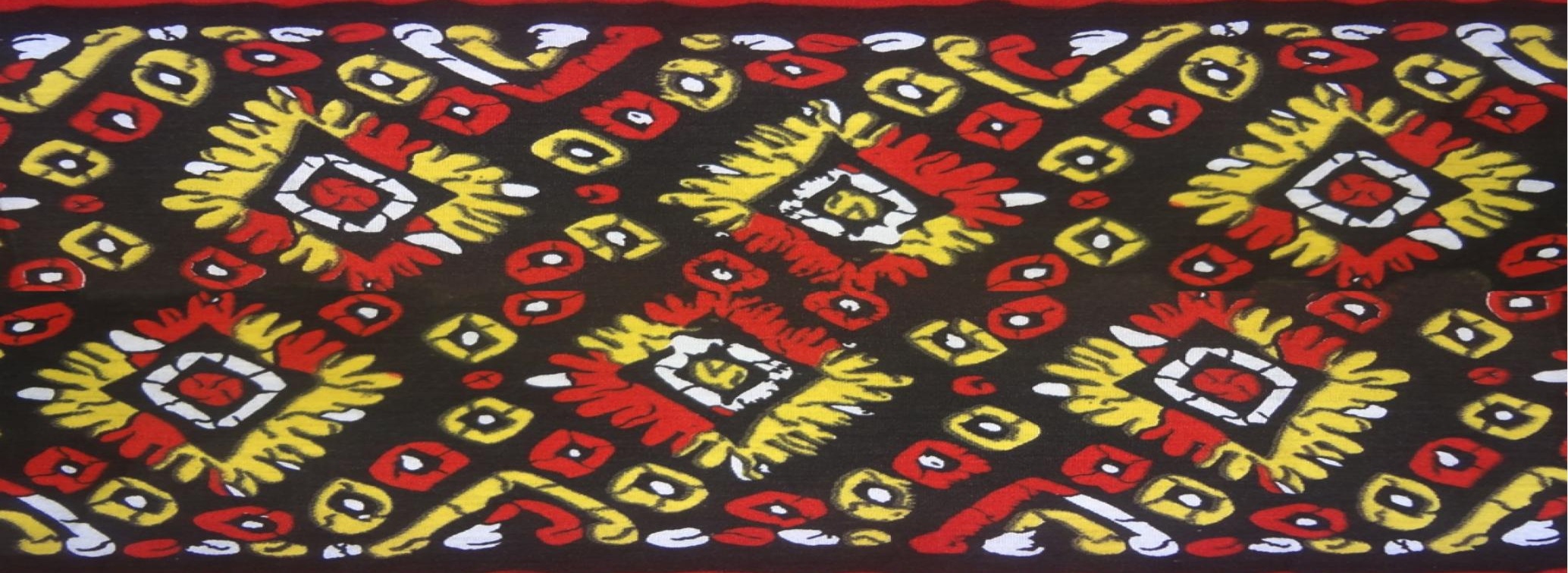

Education Sector Response

to Early and Unintended Pregnancy:

A Review of Country Experiences

in Sub-Saharan Africa 
Harriet Birungi1; Chi-Chi Undie', Ian MacKenzie' ${ }^{1}$ Anne Katahoire2;

Francis Obare1; Patricia Machawira ${ }^{3}$

1. Population Council

2. Child Health and Development Centre, Makerere University, Uganda

3. UNESCO/ Eastern and Southern Africa Regional Office. 
The STEP UP (Strengthening Evidence for Programming on Unintended Pregnancy) Research Programme Consortium generates policy-relevant research to promote an evidence-based approach for improving access to family planning and safe abortion. STEP UP focuses its activities in five countries: Bangladesh, Ghana, India, Kenya, and Senegal. STEP UP is coordinated by the Population Council in partnership with the African Population and Health Research Center; The International Center for Diarrhoeal Disease Research -Bangladesh (icddr,b), the London School of Hygiene and Tropical Medicine; Marie Stopes International; and Partners in Population and Development. STEP UP is funded by UK aid from the UK Government. www.stepup.popcouncil.org

Please address any inquiries about STEP UP to the RPC co-directors:

Dr. Harriet Birungi, hbirungi@popcouncil.org

Dr. Ian Askew, iaskew@popcouncil.org

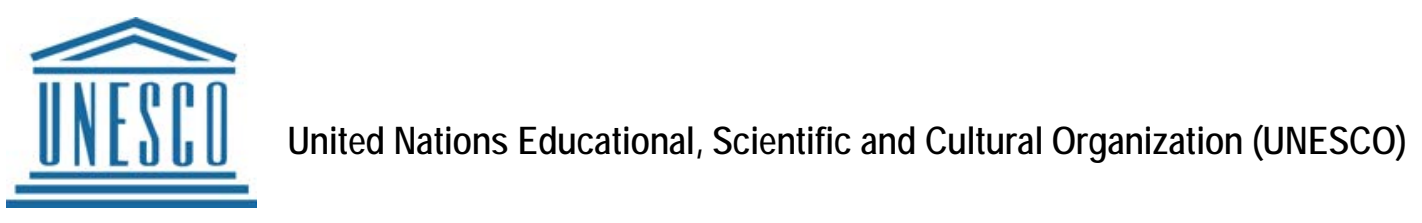

UNESCO - the United Nations Educational, Scientific and Cultural Organization - is a specialized United Nations agency that was founded on 16 November 1945. UNESCO promotes international co-operation among its 195 Member States and eight Associate Members to contribute to the building of a culture of peace, the eradication of poverty, sustainable development and intercultural dialogue through education, the sciences, culture, communication and information. UNESCO is the lead agency on sexuality education, developing tools and guidance such as the International Technical Guidance on Sexuality Education (2009) which are used by ministries and civil society in the development of sexuality education curricula, policies and implementation support. Technical support is provided at country and regional level to ministries of education and civil society organizations in their efforts to strengthen HIV and health education.

\section{POPULATION COUNCIL \\ Ideas. Evidence. Impact.}

The Population Council confronts critical health and development issues-from stopping the spread of HIV to improving reproductive health and ensuring that young people lead full and productive lives. Through biomedical, social science, and public health research in 50 countries, we work with our partners to deliver solutions that lead to more effective policies, programs, and technologies that improve lives around the world. Established in 1952 and headquartered in New York, the Council is a non-governmental, non-profit organization governed by an international board of trustees. www.popcouncil.org

Suggested citation: Harriet Birungi; Chi-Chi Undie, Ian MacKenzie; Anne Katahoire; Francis Obare; Patricia Machawira. 2015. Education Sector Response to Early and Unintended Pregnancy: A Review of Country Experiences in Sub-Saharan Africa. STEP UP and UNESCO Research Report 


\section{Table of Contents}

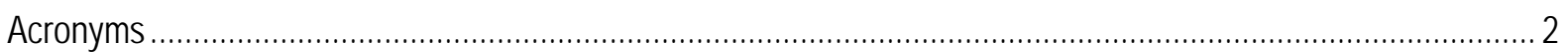

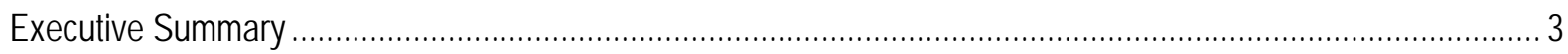

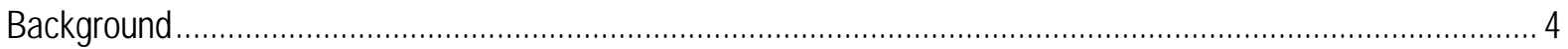

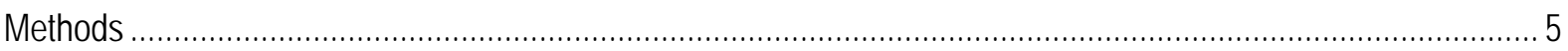

Education Sector Policies for Pregnant Students and Adolescent Mothers ................................................... 6

Integration of Pregnancy Prevention into Sexuality Education Curricula .....................................................15

School Environment and Pregnant Students/Adolescent Mothers.................................................................... 25

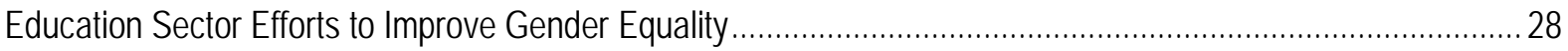

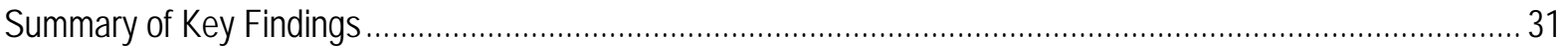

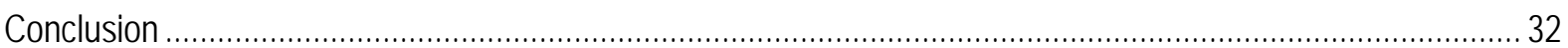

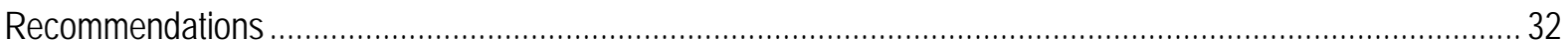

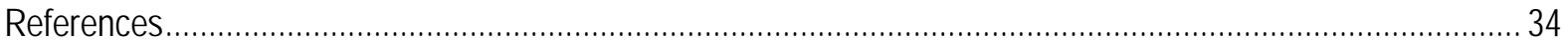




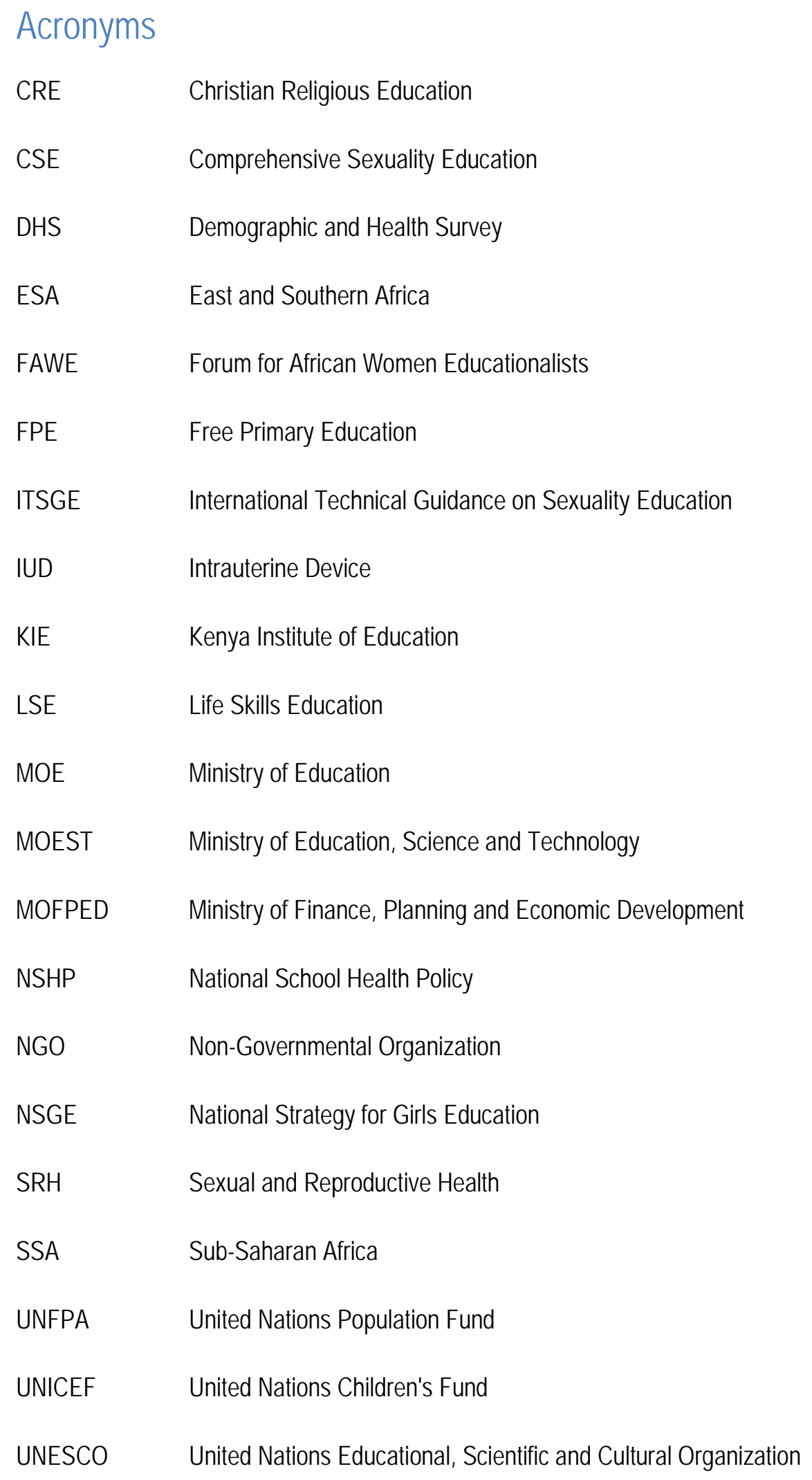




\section{Executive Summary}

In Sub-Saharan Africa (SSA), early and unintended pregnancy leads to a colossal loss of educational opportunities for girls: A high proportion of pregnancies among adolescent girls aged 15-19 years in the region are unintended, and nearly all adolescent girls who have ever been pregnant are out of school in most SSA countries. Existing studies that show associations between early/unintended pregnancy and school dropout lead to critical questions about how the education sector is responding to the issue in SSA. Conducted from August 2014 to April 2015, this review was devoted to an examination of such responses across six countries, namely: Botswana, Kenya, Malawi, Tanzania, Uganda and Zambia. The review focused on several key issues, including:

o Education sector policies for pregnant students and adolescent mothers;

o Integration of pregnancy prevention into sexuality education curricula;

o The school environment as it pertains to pregnant students and adolescent mothers; and

o Education sector efforts to improve gender equality.

The study drew on a desk review of published literature and policy and programme documents from Ministries of Health and Education in the selected countries. In addition, supplementary qualitative data were gathered through in-depth interviews with 23 key informants in Tanzania, Uganda and Zambia.

Key findings from the study are as follows:

1. Only three of the six countries (Botswana, Kenya, Zambia) have official school re-entry policies that are not in draft form.

2. None of the six countries examined utilize a continuation policy for school re-entry (which would allow pregnant learners to remain in school for as long as they would like, and not require compulsory leave after giving birth).

3. Some policies related to school re-entry convey mixed messages, resulting in uncertainties in regard to how policy implementation should occur.

4. Despite efforts and progress in the area of curricula development, none of the countries examined currently offer comprehensive sexuality education (CSE) as defined by UNESCO, and pregnancy prevention is not a central feature of the topics taught under life skills education or CSE across the six countries. Where pregnancy prevention is taught, it is introduced too late (i.e., at the secondary school level alone).

5. Programs in the six countries working to prepare school environments to receive pregnant learners/adolescent mothers were difficult to locate, plausibly due to a lack of documentation and low rates of institutionalization by Ministries of Education.

6. Literature could not be found on official policies, guidelines, or systems in place addressing the link between schools and health services, although a few policies encourage such linkages for the benefit of pregnant learners/adolescent mothers. This suggests that such school-health facility linkages are weak.

7. All of the countries examined have at least some elements of gender equality and sensitivity built into their life skills education curricula and have made efforts to incorporate gender sensitivity into the teacher training curricula.

In conclusion, the existence of national policies and guidelines (whether in official or draft form) to promote education sector responses to early/unintended pregnancy demonstrates the commitment of countries to respond to this critical issue. However, countries in the East and Southern Africa region would benefit from intensive support to address the gaps identified. As many policies are still in draft form, the timing is opportune to provide such support, drawing on findings from this study. 


\section{Background}

Early and unintended pregnancy is a major public health issue. This is particularly the case in subSaharan Africa (SSA), where adolescent girls experience the highest rates of pregnancy in the world. ${ }^{1}$ A high proportion of pregnancies among adolescent girls aged 15-19 years in SSA are unintended, ranging from 39\% in Tanzania to 59\% in Kenya (Table 1). One of the greatest health challenges associated with adolescent pregnancy is unsafe abortion with the consequences of severe complications. ${ }^{2}$ It is, for instance, estimated that $25 \%$ of unsafe abortion cases in SSA occur among adolescent girls. ${ }^{3}$ In addition, hospital-based studies in various countries in the region show that a high proportion of women seeking post-abortion care services in health facilities are below 20 years: $17 \%$ in Kenya, 21\% in Malawi, between 49\% and 58\% in Tanzania, 60\% in Zambia, and 68\% in Uganda. ${ }^{4}$

Table 1: Percent distribution of adolescent girls aged 15-19 years by pregnancy experience

\begin{tabular}{|c|c|c|c|}
\hline Country & Ever pregnant (\%) & $\begin{array}{r}\text { Unintended } \\
\text { pregnancies (\%) }\end{array}$ & $\begin{array}{r}\% \text { out of school among } \\
\text { ever pregnant }\end{array}$ \\
\hline Kenya $\quad$ (2008-09 DHS) & 17.7 & 58.8 & 97.8 \\
\hline Malawi $\quad(2010 \mathrm{DHS})$ & 25.6 & 43.5 & 96.6 \\
\hline Tanzania (2010 DHS) & 22.8 & 39.3 & 98.7 \\
\hline Uganda (2011 DHS) & 23.8 & 47.4 & 97.8 \\
\hline Zambia (2007 DHS) & 27.9 & 58.0 & 95.1 \\
\hline
\end{tabular}

Other negative health outcomes associated with adolescent pregnancy include anaemia, malaria, sexually-transmitted infections (including HIV), post-partum haemorrhage, obstetric fistula, and mental disorders such as depression. Indeed, $23 \%$ of the overall burden of disease (disability-adjusted life years) due to pregnancy and childbirth is borne by adolescent girls, although they only account for $11 \%$ of all births globally. ${ }^{5}$

The myriad health issues potentially associated with adolescent pregnancy tend to eclipse the education-related effects of this predicament. Yet, early and unintended pregnancy leads to a colossal loss of educational opportunities, which in itself results in perennial limitations on female life chances. Nearly all adolescent girls who have ever been pregnant are out of school in most SSA countries (ranging from 95\% in Zambia to 99\% in Tanzania; Table 1). Although this evidence does not give a clear indication of whether pregnancy contributed to school dropout, other studies lend some clarity to this question. A study in Botswana, for instance, showed that between 1998 and 2002, pregnancy was the major reason for girls dropping out of secondary school, accounting for 56\%. 6 In Kenya, it was estimated that between 10,000 and 13,000 girls leave school each year due to pregnancy. ${ }^{7}$ In addition, preliminary findings from an ongoing study by the Population Council in Homa Bay County, Kenya, identify pregnancy as the most common reason for girls being out of school (accounting for nearly $70 \%$ of all female school dropout cases). ${ }^{8}$

This pattern is consistent across other countries such as Tanzania, Uganda, and Zambia. In Tanzania, 2012 estimates indicate that 7,138 adolescent girls from the mainland dropped out of school due to 
pregnancy, ${ }^{9}$ while a Uganda study found that pregnancy was the most common reason cited by teachers (34\%) and students (65\%) for girls being out of school in the country. ${ }^{10}$ In Zambia, 13,634 adolescent girls were estimated to have dropped out of school due to pregnancy in 2009.11

The glaring associations between early/unintended pregnancy and school dropout lead to critical questions about how the education sector is responding to the issue in SSA. This is particularly the case given that education is a right, regardless of a student's pregnancy or motherhood status. In recognition of this reality, it is incumbent upon schools to prepare the school environment to meet the needs of pregnant students and adolescent mothers. As school officials are authorized to regulate the learning environment, they can help ensure that it is protective and supportive. Furthermore, from the age of five, many children spend most of their time in school with teachers, who are often viewed as trusted sources of information. The lengthy duration of children's schooling also provides an opportunity for long-term programming using formal educational curricula. Not incorporating pregnancy prevention into sexuality education curricula is a missed opportunity, as is neglecting to promote gender equality, which could help ensure that girls remain in school, and that girls and boys alike are motivated to play a role in ensuring that this happens.

This review is therefore devoted to an examination of education sector responses across six countries, namely: Botswana, Kenya, Malawi, Tanzania, Uganda and Zambia. It focuses on several key issues, including:

1. Education sector policies for pregnant students and adolescent mothers;

2. Integration of pregnancy prevention into sexuality education curricula;

3. The school environment as it pertains to pregnant students and adolescent mothers; and

4. Education sector efforts to improve gender equality.

The four issues outlined above are explored by individual country, where appropriate, and topically, where similarities are shared between all six countries render individual examination superfluous. Although an original intention of this review was to also include school linkages to health services for pregnant students and adolescent mothers as part of its content, further investigation found that literature on the topic is virtually non-existent. ${ }^{12}$ Nonetheless, these linkages are critical from the perspective of pregnancy prevention, and future research would be helpful in documenting the practices currently in place.

\section{Methods}

This report draws on a desk review of pertinent literature across the six countries, and is supplemented by in-depth interviews and focus group discussions with key informants purposively selected from three countries (Tanzania, Uganda, and Zambia). In regard to the desk review, Google Scholar was used as the primary search method to retrieve relevant literature. A variety of search term combinations appended to the country names formed search phrases used to retrieve relevant materials. 
The search terms were as follows: "life skills, sexuality education, re-entry policy, readmission policy, gender equality, gender equity, gender parity, gender policies, affirmative action, education sector policies, and school health policies." The formula for the searches followed the structure demonstrated below:

Country + "women's/gender," + "parity/equality/equity," + "education,"

which, for example, would appear as: Botswana, gender parity, education

UNESCO staff/associates also provided some of the Government policies (some of which were in draft form) that informed the review and that would have been impossible to obtain without such assistance. Finally, some materials were located by searching specific article titles. This was done when reviewed documents referenced materials that were not found using the search protocols listed above.

Qualitative data collection was facilitated by UNESCO offices in the countries concerned. In Tanzania, Uganda, and Zambia, key informant interviews were conducted with representatives of the Ministries of Education and developing partners, including UNESCO, UNFPA, and UNICEF (and, in the case of Tanzania, the Forum for African Women Educationalists [FAWE]). Focus group discussions (FGDs) were also carried out with head teachers and teachers, students, and parents in the 3 countries. A total of 23 key informant interviews and 7 FGDs were conducted across these countries.

\section{Education Sector Policies for Pregnant Students and Adolescent Mothers}

Three different types of policies and practices directed towards pregnant learners in SSA are outlined in the literature, ${ }^{13}$ namely, expulsion, re-entry, and continuation:

o Expulsion policies immediately remove pregnant learners from the school system and offer no prospects of returning to school.

o Re-entry policies necessitate a compulsory leave of absence before a student may re-enter school, often a different school. Individual re-entry policies differ, particularly in regards to the length of time girls must withdraw from school.

o Continuation policies are the most progressive policies, allowing pregnant learners to remain in school for as long as they would like, and not requiring compulsory leave after giving birth.

None of the six countries included in this study exercise continuation policies or practices. However, the Kenya National School Health Policy (NSHP) does contain policy language that leans towards a continuation approach. Table 2 provides an overview of the policies in the six selected countries. Specific experiences within each study country are examined further in the sub-sections below.

\section{Botswana}

Botswana has the longest standing re-entry policy among the six countries examined in this review. Botswana utilizes a re-entry policy instilled in the Botswana Education Regulations passed in 1978. In 1995 , a government circular standardized the re-entry process per the original guidelines. The policy stipulates that pregnant girls are to be withdrawn from school and re-admitted to a different school no 
sooner than twelve months after the cessation of the pregnancy. ${ }^{14}$ Pupils are not allowed to sit for examinations while pregnant or within six months of delivery, and their re-entry to school or ability to sit for examinations is contingent upon approval from the Minister of Education.

\begin{tabular}{|c|c|c|c|c|c|c|}
\hline Country & $\begin{array}{l}\text { Relevant } \\
\text { Policies }\end{array}$ & $\begin{array}{l}\text { Policy } \\
\text { Practices }\end{array}$ & $\begin{array}{l}\text { Mandatory } \\
\text { Pregnancy } \\
\text { Screening }\end{array}$ & $\begin{array}{l}\text { Amount leave } \\
\text { before re- } \\
\text { entry }\end{array}$ & $\begin{array}{l}\text { Per Policy, } \\
\text { Currently } \\
\text { Pregnant } \\
\text { Girls Allowed } \\
\text { in School? }\end{array}$ & $\begin{array}{c}\text { Policy } \\
\text { Established } \\
\text { or in Draft } \\
\text { Form }\end{array}$ \\
\hline Botswana & $\begin{array}{l}\text { Republic of } \\
\text { Botswana } \\
\text { Education } \\
\text { Regulations } \\
\text { (1978) }\end{array}$ & Re-entry & Yes & $\begin{array}{l}12 \text { month } \\
\text { leave of } \\
\text { absence }\end{array}$ & No & Established \\
\hline Kenya & $\begin{array}{l}\text { Return to } \\
\text { School Policy } \\
\text { Guidelines } \\
\text { (1998) } \\
\text { National School } \\
\text { Health Policy } \\
\text { (2009) }\end{array}$ & $\begin{array}{l}\text { Re-entry } \\
\text { Re-entry }\end{array}$ & Yes & $\begin{array}{l}\text { Unclear } \\
6 \text { months }\end{array}$ & 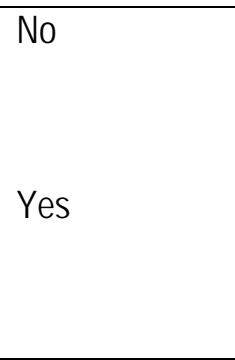 & $\begin{array}{l}\text { Established } \\
\text { (Return to } \\
\text { School Policy, } \\
\text { 1994) } \\
\\
\text { Established }\end{array}$ \\
\hline Malawi & $\begin{array}{l}\text { MOEVT } \\
\text { Readmission } \\
\text { Policy (1993) }\end{array}$ & Re-entry & Unknown & $\begin{array}{l}12 \text { month } \\
\text { suspension, } \\
\text { re-entry into } \\
\text { next academic } \\
\text { year }\end{array}$ & No & $\begin{array}{l}\text { Revised Re- } \\
\text { entry } \\
\text { Guidelines in } \\
\text { Draft Form }\end{array}$ \\
\hline Tanzania & $\begin{array}{l}\text { No official policy } \\
\text { (current } \\
\text { practice) } \\
\text { Draft Re-entry } \\
\text { Guidelines (yet } \\
\text { to be approved) }\end{array}$ & $\begin{array}{l}\text { Expulsion } \\
\text { Very limited } \\
\text { opportunity } \\
\text { for re-entry } \\
\text { Re-entry }\end{array}$ & Yes & $\begin{array}{l}\text { Re-entry after } \\
6-12 \text { month } \\
\text { suspension }\end{array}$ & No & Draft \\
\hline Uganda & $\begin{array}{l}\text { No official policy } \\
\text { (current } \\
\text { practice) } \\
\text { Draft National } \\
\text { School Health } \\
\text { Policy (yet to be } \\
\text { approved) }\end{array}$ & $\begin{array}{l}\text { Suspension } \\
\text { Expulsion } \\
\text { Re-entry at } \\
\text { different } \\
\text { schools } \\
\text { Re-entry }\end{array}$ & Yes & $\begin{array}{l}\text { Left to } \\
\text { discretion of } \\
\text { Head Teacher } \\
\text { Unclear }\end{array}$ & $\begin{array}{l}\text { No (unless } \\
\text { Head Teacher } \\
\text { allows it) }\end{array}$ & N/A \\
\hline Zambia & $\begin{array}{l}\text { MOE Re-entry } \\
\text { Policy (1997) }\end{array}$ & Re-entry & Yes & $\begin{array}{l}12 \text { month } \\
\text { leave of } \\
\text { absence }\end{array}$ & Yes & Established \\
\hline
\end{tabular}


There is no mechanism to follow up on or keep track of girls who drop out of school due to pregnancy. ${ }^{15}$ Consequently, girls are left to their own or their parents' initiative to find a new school and begin the reentry process. Further, there is no legal backing to the re-entry policy and the Ministry of Education has not expended much effort in disseminating the policy to schools or to promoting awareness among communities. As a result, knowledge about the re-entry policy is low within the education sector and within communities. ${ }^{16}$

\section{Kenya}

Kenya has education sector policies that specifically address pregnant students and adolescent mothers. The relevant policies are the 1994 "Return to School Policy" (hereafter referred to as 're-entry policy') ${ }^{17}$ and the 2009 "National School Health Policy." 18 The re-entry policy stipulates that girls may return to school (preferably, a different school) after giving birth; however, no definitive time frame details how long the period of leave should be. ${ }^{19}$ Despite its longstanding tenure, the re-entry policy has never been properly implemented or disseminated in recent years (An MOE circular was issued in the mid-1990's; ${ }^{20}$ however, no evidence was found of the policy being circulated again afterwards).

The NSHP appeared in 2009 and fills some of the school continuity void confronted by pregnant students. The NSHP states that pregnant girls should be allowed to continue with their studies for as long as possible, that "girls will undergo voluntary medical screening once per term," and that schools should provide special facilities for nursing mothers at school. ${ }^{21}$ No time frames or guidelines are provided to School Heads in regards to what "as long as possible" actually entails. Furthermore, the provision of nursing facilities for adolescent mothers has been found to be rarely implemented. ${ }^{22}$ The greater majority of schools are unlikely at this point to allow, let alone promote, this component of the NSHP. 23

There are incongruities between policy statements in the NSHP and best practices identified by School Heads. The NSHP states, "to all intents and purposes the school fraternity shall act as if nothing had happened ... (and) teenage mothers in school shall not be allowed to form groupings e.g. of young mothers clubs." 24 The policy also directs schools to counsel the affected girls and their parents. In practice, however, some School Heads stress the importance of student mother support groups, mentorship programs, and bringing in outside speakers with personal experience of early pregnancy. ${ }^{25}$ Literature also shows a failure to adequately counsel the affected girls and their parents. ${ }^{26}$ Further, a lack of legal backing makes the policy weak and unenforceable. ${ }^{27}$ There is a disconnect between the policy and its practice; however the result is not necessarily negative. The use of student support groups and utilizing outside speakers counters NSHP policy statements, but is used as a way to support pregnant students and adolescent mothers and can be thought of as a positive result. On the other hand, the failure to counsel girls and their families is clearly a negative outcome.

In a recent Population Council baseline survey, $63 \%$ of School Heads had heard of the NSHP, compared to $80 \%$ who stated they had heard of the re-entry policy (despite not having ever seen a copy of it). ${ }^{28}$ Knowledge of the actual contents of both policies was much lower, comparatively. Nevertheless, most schools have unwittingly implemented some of the policy elements based on their own personal 
convictions over what should be done - or (for those who are aware of the policies), based on their own interpretations of the policy language. ${ }^{29}$ Some of these implementation strategies appear to be very progressive.

Current practices in Kenyan schools generally allow for re-entry at the discretion of the School Head without sufficiently detailed policy implementation guidelines to guide the process. ${ }^{30}$ School Heads and teachers are willing to receive the girls and understand the importance of allowing the girls to return. ${ }^{31}$ School Heads hold the authority in deciding how long a girl may remain in school while pregnant, and the School Head re-admitting the student often does so on a selective basis where preference is given to strong academic performers who demonstrate remorse for becoming pregnant. ${ }^{32}$ Further, within the education and health sectors, there is no system of tracking or following-up on girls who go on leave due to pregnancy and schools perform no follow up of their own. 33 Unless girls or their families push for re-entry, adolescent mothers are unlikely to resume their studies. Of the estimated 10,000 to 13,000 of girls who drop out of school every year due to early and unintended pregnancy, most will not return. ${ }^{34}$ One Kenya-based study identified the major challenges preventing the implementation of re-entry policies by Head Teachers in Kenya as the lack of policy guidelines, fear of the school being ostracized by the community, fear of having mothers at school, and concerns about the harassment affected girls will receive from their peers. ${ }^{35}$ Recent findings from a Population Council baseline study highlight financial constraints and a lack of child care assistance as the top two barriers hindering out-of-school teenage mothers from re-entering school. ${ }^{36}$

\section{Malawi}

The Malawian Ministry of Education put in place a re-entry policy for adolescent mothers in 1993, and the procedures for implementing the policy were further revised in 2006. ${ }^{37}$ Currently, the revised reentry guidelines discussed below are pending final approval. The guidelines for the policy stipulate that girls are immediately suspended upon discovery of their pregnancy for one year, and will be allowed readmission at the beginning of the next academic year following their suspension. Counselling services are to be provided to the affected girl and the boy responsible for the pregnancy (if appropriate), both at the point of withdrawal from school and at the point of re-entry. Malawi's re-entry policy is also explicit on the fact that boys who impregnate students will face an equivalent suspension of one year and will be re-admitted in the same timeframe. In practice, however, boys are rarely suspended for the full year. ${ }^{38}$ Although the right of such students to continue their education should be upheld, the unequal treatment of girls in this situation, compared to their male peers, is of concern.

Both female and male students are only afforded one opportunity for re-entry during their academic careers. Repeat pregnancies are not tolerated. Girls often re-enter at a different school; however, the policy is silent about the issue and seemingly allows for the affected girls to decide what is best for them. The policy also stipulates that School Heads must submit letters that are eventually passed on to the MOE, documenting the girl's withdrawal and re-entry. It is unclear if there is a systematic method of tracking the affected girls, but some effort is being made to document the process.

There are no evaluations or analyses describing how many girls actually re-enter after withdrawal due to pregnancy or concerning the implementation of the re-entry policy; therefore, it is impossible to give a 
wholly accurate portrayal of the effectiveness of the policy. ${ }^{39}$ While many students take advantage of the policy, there have been reports of Head Teachers refusing re-entry to adolescent mothers. ${ }^{40}$ These refusals may be attributed to numerous factors such as poor policy dissemination, or bias against readmission. Further, there is no provision of education services for students during their suspension. ${ }^{41}$

\section{Tanzania}

Tanzania currently has no official policy in place for the re-entry of adolescent mothers. Historically the longstanding practice has been immediate expulsion of pregnant pupils with no prospect of re-entry into public school. ${ }^{42}$ Most Head Teachers believe they are legally mandated to expel pregnant students; however, the Center for Reproductive Rights reports there is no law or policy directing them to do so. ${ }^{43}$ Rather, the practice of expulsion is ingrained within individual school rules and practices instead of official policy. Similarly, routine compulsory pregnancy testing is conducted without legal basis as well. 44

The Government of Tanzania is finalizing a policy on the re-entry of adolescent mothers. ${ }^{45}$ In 2009 , the Tanzanian Government allowed pregnant students to sit for national examinations. The draft re-entry policy guidelines of January 2011 include: pregnant school girls being allowed to sit for their national exams if diagnosed within exam timeframe; only one re-admission opportunity for pregnant girls; conditional re-admission within 6-12 months after giving birth, with a medical doctor's approval; and mandatory disclosure of the boy or man responsible for the pregnancy. It is noteworthy that Tanzania has strict laws against impregnating a minor under the age of 18 , which is considered statutory rape, and carries harsh prison sentences of up to 30 years. ${ }^{46}$ Pregnant minors are often arrested and questioned regarding who is responsible. 47

The draft re-entry policy also calls on the Government to sensitize education officials and communities about the re-entry policy and procedures. In discussing the issue of school re-entry, respondents from the Ministry of Education and schools expressed a preference for girls entering a different school from the one at which the pregnancy occurred. This was a common refrain among teachers and students alike, due to concerns around stigma and worries about the perceived negative influence that reentering girls would have on their peers:

The other children will say a lot, and this child will be stigmatized. So, the best thing is to transfer her where the problem is not known ... In the same school she cannot study comfortably when she returns (FGD with Teachers).

She will be polluting the rest who will say, 'Ah ha! So, I can just play sex, get pregnant, and soon afterwards I can come back to school after delivery?' We will be inviting prostitution, and that is risk behaviour (FGD with Teachers).

When others girls see her, they might envy her and also want to have a child, and she may also share her sexual experiences with her friends, and they may also want to try it out. So, it is not good for her to return to the same school. She should go elsewhere and begin a new life where no one knows her. And by the time they find out, she would have finished her studies and moved on (FGD with Students). 
Respondents were much more comfortable with the idea of girls returning to the same school if their pregnancy was not publicly known, and they were therefore not suspended or expelled as a result. This raises questions about the potential role of suspension/expulsion (versus early/unintended pregnancy itself) in stigmatizing the school re-entry process.

\section{Uganda}

Uganda currently has no official policy on school re-entry for adolescent mothers in place. The common education sector response to early or unintended pregnancy has been suspension or expulsion of pregnant girls. Those with supportive parents can return to school after delivery, but typically seek admission into a different school.

The country has drafted National School Health Policy which was recently approved by the Ministry of Education's senior management, and is currently awaiting cabinet approval. This version of the draft NSHP calls for pregnancy screening once per term, pregnant students to continue their studies for as long as possible and linked to antenatal services, counselling services of pregnant girls, their families, and boys responsible for the pregnancy, and re-entry after an appropriate amount of time into the same or a new school. ${ }^{48}$ Further, pregnant students are allowed to sit for their national exams. ${ }^{49} \mathrm{At}$ this time the policy does not provide detail as to what an appropriate amount of time entails, which could result in a wide discrepancy of practices similar to the re-entry practices in Kenya.

There is no method of tracking how many girls are expelled or drop out due to pregnancy in Ugandan schools at the district level. 50 A FAWE study showed the views of about 300 teachers concerning what happens when a girl becomes pregnant: $27.8 \%$ stated suspension, $25.6 \%$ indicated expulsion, $5.7 \%$ reported continuation, and the remaining $14.4 \%$ did not know what happens. ${ }^{51}$

Officials interviewed at the Ministry of Education and Sports referred to the lack of a clear implementation framework as one of the major drawbacks in the implementation of health interventions in school:

For a long time, we have lacked a framework as a Ministry for guiding health interventions in school. Now that the School Health Policy has been validated and endorsed by top management and a Cabinet paper is being prepared, we have reached the last stage in this process (Key Informant Interview).

Key informants and teachers were largely in favour of girls re-entering new schools, rather than the ones at which the pregnancy occurred. This stance seemed to be informed by concerns regarding stigma and discrimination from teachers and students, and by the perception that re-entering girls would perform better in a new school environment:

$[B]$ oth the teachers and students can make the girl's life uncomfortable. The other children will call her 'mother,' and if she does anything wrong in the classroom, a teacher [might] say, 'How can a whole mother like you behave like that when you already have a child?' So, they are safer elsewhere where their history is not known (FGD with Teachers). 
Nonetheless, teachers also highlighted examples of girls being supported by fellow students upon reentering school:

I heard of a case in another school where the students took a collection each week for the babies' milk because the girl could not afford it, and her guardian had threatened to withdraw her from school so that she could work and support the baby. But the other students heard this and decided to help out (FGD with Teachers).

Key informants, teachers, and students all alluded to the need for a multi-sectoral approach in order to ensure that re-entry policies are effectively implemented. Successful implementation of re-entry policies will require the participation of a range of community members and stakeholders:

The successful implementation of this policy is going to depend a lot on the sensitization of parents and communities about the importance of girls who have been pregnant and delivered returning to school, and reasons have to be given as to why parents have to provide the necessary social support and resources to enable girls to do this. This necessitates bringing on board other Ministries, such as those of Gender, Community Development, and maybe even Justice, because laws may have to be legislated to ensure that parents do not abandon and send their daughters out of their homes due to pregnancy, as has been happening ... What I am saying is that this is an issue that is going to need other sectors to come on board. It cannot be solved by the Ministry of Education enacting a policy on re-entry (Key Informant Interview).

Since the girl has no home, no job, and no money of her own, she is at the mercy of her parents and maybe the person who made her pregnant. So, even if we say she should return to school, who will look after her baby? Where will she get the money to buy her milk and other things that she needs? The issue is much more complicated than having a re-entry policy and all these issues have to be addressed if the re-entry policy is to work in Uganda (FGD with Teachers).

\section{Zambia}

The Zambian Ministry of Education instituted a re-entry policy for teenage mothers in 1997,52 with revised guidelines in 2012. The Ministry of Education, Science, Vocational Training, and Early Education keeps track of girls re-admitted after delivery. Between 2005 and 2012, nearly 100,000 girls dropped out of primary school. ${ }^{53}$ Of these, slightly more than a third (37.7\%) returned to school. At the secondary school level, fewer girls dropped out due to pregnancy (nearly 14,000), and more than half $(60 \%)$ returned to school. These facts underscore the importance of the proper timing of CSE delivery, as mentioned elsewhere in this report.

The school re-entry policy language in Zambia stipulates a leave of absence ranging from six to no longer than twelve months after delivery before re-entry to school. ${ }^{54}$ Re-entry policy guidelines further suggest that pregnant girls and the boys responsible for the pregnancy should both be counselled upon withdrawal from school and at the time of re-entry. On paper, boys (in school) responsible for getting girls pregnant should be suspended for the equivalent amount of time as the pregnant girls are placed on a leave of absence; however, in practice, they are usually suspended after the girl gives birth until she returns to school 12 months later, if at all. It is important to point out that suspensions for students due to pregnancy (both the male and female student involved) infringe upon their right to education. 
At the point of withdrawal from school, parents and school administrators sign an agreement stating the girl will re-enter no later than one year after giving birth. Guidelines produced by the MOE in 2004 further specify that girls should remain in school until the seventh month of their pregnancy unless advised to leave school earlier by a doctor (researchers found no evidence of this actually happening, however). ${ }^{55}$ The schools are involved in submitting paperwork that documents the withdrawal, pregnancy and other information to the Ministry of Education. Thus, there is some basic tracking, or at least documentation system in place of the affected girls. The re-entry policy suggests girls should reenter at a different school but allows them to remain at their original school should they choose to do so. Further, repeat pregnancies are not grounds for permanent expulsion however further detail is not provided on how to handle them. ${ }^{56}$ Pregnancy screening is also common practice and is suggested as part the re-entry guidelines to be done at the beginning of every term. ${ }^{57}$

An evaluation of the implementation of the re-entry policy showed very strong indicators pertaining to knowledge about the policy. ${ }^{58}$ One study showed that out of 128 education sector personnel surveyed, $100 \%$ knew about the policy and were able to describe its contents. ${ }^{59}$ MOE figures from 2010 show readmission rates were 36-43\% between 2002 and 2009. 60 Despite the policy, from 2005-2007 the number of girls who dropped out of school due to pregnancy rose from 7,700 to 9,700 with the poor and rural areas hardest hit. ${ }^{61}$ Discussions with teachers provided more insight into this issue:

Schools are widely scattered, especially in rural areas. It is therefore not very easy to just transfer from one school to another without it involving travel of a long distance, which introduces another dynamic of transport costs. Secondly, some of these girls are coming from poor families who cannot look after their babies and at the same time give the girl transport to travel to school (FGD with Teachers).

Children coming from poorer families are the ones who mostly do not return to school. Among the rich, the barriers are fewer: They can take care of the grandchild very well, providing for the needs of the mother, as well as those of the child. But for those from poor families, they have nowhere to start. So, even with the policy, they cannot return to school unless the issue of child care is sorted out, as well as that of their own welfare (FGD with Teachers).

A 2012 review of the implementation of the re-entry policy62 also highlights reasons why re-entry rates are not higher:

One of the reasons for the relatively low rates of re-entry is that the implementation guidelines of the policy were not well known to the implementers. In fact, approximately 30 percent of the girls interviewed disclosed that they left school without following the normal procedure. This has implications on the re-entry rate as data suggests that girls who did not inform school authorities about their pregnancy were less likely to re-enter school after delivery than girls who informed the school authorities (61\% vs $84 \%$ ). Additionally, 75 percent of the girls who did not return to school cited the lack of financial support for the welfare of their children and themselves as a major reason for them not to continue with school ... Another factor that limited the effectiveness of the policy is that there was also a lot of stigma that the girls who become pregnant faced at school. This likely discouraged some girls from re-entering after giving birth and made it more difficult for those who returned to be successful and remain in school. 
Discussions with teachers, students, and parents confirmed the existence of stigma not only at the school level, but also at home and in the wider community. FGDs revealed a sense among teachers and parents that the re-entry policy hindered beneficiaries from 'learning from their mistakes.' There were also concerns about a possible increase in school pregnancies as a result of allowing adolescent mothers back in school. The concerns led to suggestions that special schools be established solely for adolescent mothers:

My fear is that this girl who has already experienced sex and gotten pregnant may encourage the younger and more innocent ones also to try it out. After all, even if they get pregnant, they can always return to school. That is my fear. Otherwise, it is a very good policy and should be promoted, but the Ministry of Education can also put up special schools for them (FGD with Teachers).

Nevertheless, some teachers highlighted the potential of adequate counselling to mitigate the issues of concern. This is sometimes brought about by parents deciding not to inform the school about their daughters' pregnancies. As a consequence, schools are sometimes unable to provide the needed support.

This is because they are not well counselled after childbirth. The mothers just take the babies and put the girls back in school, and do not even bother to inform the schools that this girl had a baby. ... The problem that comes is that the girls keep falling pregnant. The girls are not being counselled properly (FGD with Teachers).

As intimated by a Guidance and Counselling teacher:

There is a girl in this school who came here from another school, having dropped out of school and given birth. She was brought by her aunt and we sat down with her and counselled her, and her behaviour has changed. She works hard and is now one of the prefects, and others do not know her history. But I have been following up on her and checking her progress, and she is doing well (FGD with Teachers).

In summary, despite the presence of national policies on school re-entry for adolescent mothers, the reality for many pregnant girls does not align with the policy language. Social stigma, cultural practices, differing levels of implementation, and policy ignorance all contribute to low re-entry rates and act as barriers to re-entry despite supportive government policy. Policy implementation is often lacking, and policy language is sometimes conflicting. In Kenya, for example, while the Return to School policy implementation guidelines imply that pregnant learners should be sent home, the NSHP stipulates that such learners should be allowed to remain in school for as long as possible.

School health and re-entry policies often include directives for pregnancy screening, but do not provide explicit justification for doing so. The practice may be presented by stakeholders as helping girls identify pregnancies, although this is not written into any of the policy language reviewed. In practice, pregnancy screening seems to serve as a method to identify a pregnancy that will result in suspension or expulsion. The Kenyan NSHP and Zambian re-entry policy allow pregnant girls to remain in school and stipulate girls should be counselled and linked to antenatal services. This is the only benefit to 
pregnant girls that can be attributed with the practice (assuming the counselling and service linkage occur). There is no literature that discusses the benefit of pregnancy screening in Sub-Saharan African schools.

Overall, whether policies related to school re-entry have already been established or are still in process, the reticence toward permitting pregnant learners to remain in school is clear, and pregnancy screening is seen as important (Table 2). However, the policy language in most countries is strongly inclined toward school re-entry after a pregnant learner's delivery, with little regional coherence on the question of when such learners may re-enter school.

\section{Integration of Pregnancy Prevention into Sexuality Education Curricula}

UNESCO describes comprehensive sexuality education (CSE) as education that, "emphasizes a holistic approach to human development and sexuality [.]" Its primary goal is for "children and young people to become equipped with the knowledge, skills and values to make responsible choices about their sexual and social relationships in a world affected by HIV."63 More specifically, "sexuality education is defined as an age-appropriate, culturally relevant approach to teaching about sex and relationships by providing scientifically accurate, realistic, non-judgmental information... Sexuality Education provides opportunities to explore one's own values and attitudes and to build decision making, communication and risk reduction skills about many aspects of sexuality."64

For example, according to the Kenyan Institute of Education, "Life skills education is the study of techniques for adaptive and positive behaviour change, which enable individuals to deal effectively with the demands and challenges of everyday life... Teaching of Life Skills is aimed at equipping the learner with psychosocial competencies that would help him/ her make informed decisions, solve problems, think creatively and critically, communicate effectively, build healthy relationships, empathize with others and manage his/her life in a healthy and productive manner."65 Sexuality education is generally integrated into life skills education (LSE) curricula by the respective Ministries of Education (MOE).

A 2011 UNESCO review of sexuality education curricula in 10 East and Southern African countries found that most LSE curricula were lacking information on condom use and contraceptives, basic aspects of sexual health and sex, gender issues, and framed sexuality in negative and fear-based contexts. ${ }^{66}$ Some curricula are strong in decision-making skills and life choices, but most contain significant gaps in equipping learners with unbiased information regarding sexuality, condom use and contraceptives, abortion, the basics of human development, and human conception. 67 The basic mechanics of sex and elements of sexuality are not adequately discussed. Curriculum content for the six study countries is outlined in Table 3. 


\begin{tabular}{|c|c|c|c|}
\hline \multicolumn{4}{|c|}{ Table 3: Overview of Sexuality Education by Country by 2011 } \\
\hline Country & Standardized Curricula & $\begin{array}{c}\text { Condoms Taught (per } \\
\text { curricula) }\end{array}$ & $\begin{array}{c}\text { Other Contraceptives } \\
\text { Taught (per } \\
\text { curricula) }\end{array}$ \\
\hline Botswana & Yes & Yes & Unclear \\
\hline Kenya & Yes & No & No \\
\hline Malawi & Yes & Yes & Unclear \\
\hline Tanzania & $\begin{array}{c}\text { No standalone } \\
\text { curriculum; LSE } \\
\text { integrated into other } \\
\text { subjects }\end{array}$ & Unclear & $\begin{array}{c}\text { Only in Islamic } \\
\text { Religious Education } \\
\text { curriculum }\end{array}$ \\
\hline Uganda & $\begin{array}{c}\text { Yes, several different } \\
\text { curricula }\end{array}$ & $\begin{array}{c}\text { Onligious Education } \\
\text { curriculum }\end{array}$ & No \\
\hline Zambia & Yes & No & No \\
\hline
\end{tabular}

Another concern raised in the UNESCO report was the timing of the content within the various curricula. Topics such as puberty and reproductive development were noted as sometimes being presented in upper primary or lower secondary levels after most students have already gone through puberty. Much of the content pertaining to pregnancy prevention, including condoms and other contraceptives, was covered in secondary school levels. ${ }^{68}$ While this may have been under the presumption that the content was more age-appropriate at this level, low transition rates into secondary school preclude many adolescents from the benefits of sexuality education.

As is the case with re-entry policies, there is no guarantee that material in the LSE curricula is actually covered. In all of the countries examined, teachers face pressure to focus on examinable subjects, often at the expense of LSE. Evaluations of LSE programs revealed teachers are often inadequately trained to deliver the lessons and may feel uncomfortable discussing sexuality issues. Thus they may not teach them or schools may encounter resistance from religious groups when addressing sexuality education that deviates from a conservative, abstinence-only approach. Evaluation of LSE implementation has not been done at a national level for most of the countries; therefore, it is difficult to determine the extent to which the various curricula are actually being taught. Evaluations in Kenya suggest that there is often a considerable gap between curriculum content and what is being taught. 69

By December 2013, the six countries included in this study all became signatories to the East and Southern African (ESA) countries' commitment to deliver CSE and sexual and reproductive health services for young people. The commitment was signed by Ministers of Education and Health from twenty countries. The ESA Commitment document was based on a regional report, "Young People Today: Time to Act Now," which reviewed the trends and status of sexual and reproductive health and 
HIV among adolescents and young people in the ESA region, including CSE and service needs. The commitment targets related to CSE include increasing the number of schools that provide life skillsbased HIV and sexuality education, and increasing the number of teachers who have received training and have taught lessons in HIV and sexuality education.

Given the focus of the overall report on education sector responses to early/unintended pregnancy, the country-specific sub-sections below present what is currently known in the study countries in regards to CSE and LSE foci on curriculum content related to pregnancy prevention included in the various LSE curricula, and not the LSE curricula in their entirety. Curriculum implementation is also of equal importance and unfortunately there is limited research addressing this. For most of the countries covered in this review, only content analysis reviews of the curricula and curricula guidelines were available. Country specific status of integrating CSE and LSE at primary and secondary education levels in summarized in table 4. However, implementation evaluations for CSE and LSE are limited or non-existent for most of the countries examined. In the sub-sections devoted to Tanzania, Uganda, and Zambia, qualitative data are included to supplement the desk review information.

\begin{tabular}{|l|l|l|}
\hline \multicolumn{3}{|l|}{ Table 4: CSE integration into country curriculum at primary \& secondary school levels as of 2014} \\
\hline Country & $\begin{array}{l}\text { Inclusion of CSE in } \\
\text { primary school curriculum }\end{array}$ & $\begin{array}{l}\text { Inclusion of CSE in } \\
\text { secondary school curriculum }\end{array}$ \\
\hline Botswana & In process & In process \\
\hline Kenya & In process & In process \\
\hline Malawi & Standalone and Examinable & Standalone and examinable \\
\hline Tanzania & Integrated and Examinable & Integrated and Examinable \\
\hline Uganda & Standalone pilot 2014, delivery in 2015 & Integrated, mandatory, examinable; commencing 2017 \\
\hline Zambia & Integrated and examinable & Integrated and examinable \\
\hline $\begin{array}{l}\text { Source: Young People Today: Time to Act now, East and Southern Africa Commitment } \\
\text { One year in review 2013-2014 }\end{array}$ \\
\hline
\end{tabular}

\section{Botswana}

Botswana is in the process of integrating CSE into its primary and secondary school curricula. The country is also currently reviewing its Life Skills Framework of 2011, its School Health Policy, and its Adolescent Sexual and Reproductive Health training manual of 2012.

Draft documents examined as part of this review call for a consolidated life planning skills curriculum to be developed, but are vague in regard to actual LSE or sexuality education content to be integrated into the school curriculum. 70 UNESCO identified the most recent curriculum in place at a national level as the, "2010 Life Skills Framework for pre-primary, primary and secondary level students." 38 The UNESCO review notes the curriculum has strong points, but it also highlights the missing elements and gaps in areas pertaining to reproductive health and physiology, sexual relationships, contraception and adolescent pregnancy, and negotiation/decision making skills as they pertain to sexual relationships. ${ }^{38}$ Abstinence education and condoms are both presented in the new draft curriculum, however, it is unclear what coverage, if any, is given to contraceptives. ${ }^{38}$ Further, the Adolescent Sexual and 
Reproductive Health Strategy Implementation Plan drafted by the Botswana Ministry of Health (MOH) identifies deficiencies in monitoring and evaluation, poor integration of sexuality issues, including gender issues and abuse, and a lack of trained teachers as gaps that need to be addressed. ${ }^{71}$

\section{Kenya}

Like Botswana, Kenya is in the process of integrating CSE into the curricula of primary and secondary schools. The Kenya Institute of Education (KIE) developed its Life Skills Education Syllabus in 2008 to be used at the national level as a stand-alone subject at both the primary and secondary school levels. ${ }^{72}$ Despite sexuality education being integrated into the LSE curriculum, closer examination suggests that very little actual sexuality education or information about sex is taught. ${ }^{73}$ Compared to the UNESCO 2009 International Technical Guidance on Sexuality Education (ITSGE), there are multiple topics that are poorly addressed or left out altogether when the sexuality education is offered. Most notably, the curriculum contains no information on condoms or other forms of contraception. The only information on pregnancy prevention is abstinence-related. ${ }^{74}$ No national level evaluations have been done to assess the effectiveness or impacts of the CSE and LSE programs in Kenya.

A 2010 survey conducted by the Kenyan Ministry of Education (MOE) showed that the implementation of the LSE curriculum in the areas under study was poor. Inadequate teacher training, limited resources, competition with examinable subjects, and a lack of supervision by the Head Teachers were found to be the leading factors for the thin implementation. ${ }^{75}$ The survey found $56 \%$ of teachers indicated they had not received LSE training. Among the teachers that did receive training, it was not comprehensive and many topics were not covered. The average duration of teacher training ranged from 1 -15 days, with the mean amount of training being 5 days. Currently, there are considerable gaps between the UNESCO Technical Guidelines, the LSE Syllabus, and what is actually being taught in Kenyan schools. ${ }^{76}$

\section{Malawi}

Malawi has integrated CSE into its primary and secondary school curricula. The Malawian Government introduced life skills education into the government school curricula in 2002 and made LSE an examinable subject in 2010.77 The primary curriculum is directed by the "Life Skills Series for Primary Levels" and "Life Skills and Sexual and Reproductive Health for Secondary Levels."78 The majority of the curriculum begins during Standard 5 and continues through the end of secondary school. The bulk of sexuality education content is delivered during secondary levels. Transition rates for Malawian students from primary to secondary school are low for both girls and boys, and many elements of the sexuality education curriculum are missed by students who dropout during primary school. ${ }^{79}$

The UNESCO review of sexuality education in 10 African countries showed some strong content in the syllabi for the LSE curriculum, however there are gaps pertaining to pregnancy prevention, human development, reproduction, and sexuality. 80 The curriculum covers both abstinence and condoms; however, no information other than an abstinence-only approach is provided in regards to preventing pregnancy, suggesting that contraceptives may not be discussed comprehensively. 
Despite LSE being an examinable subject, it is often inconsistently taught, if at all. ${ }^{81}$ Overcrowded schedules, preference for subjects related to university admission, and discomfort teaching the material are identified as major reasons for the varying levels of coverage. ${ }^{22}$ Likewise, one study noted little community awareness about what LSE actually entailed, which adds basis to another observation of many parents demanding their children not attend courses with "obscenities." 83 No studies focus on evaluating the implementation or effectiveness of the LSE curricula in Malawi. In general, data on sexuality education in Malawi is sparse; however, older studies suggest that poor implementation is likely the biggest inhibitor of the program. 84

\section{Tanzania}

Tanzania integrated CSE into its primary and secondary school curricula in 2005. Key informant interview data indicate that CSE is integrated in Science, Civics and Personality Development and Sports in the primary schools curricula and in Biology, Civics and general studies in the secondary school curriculum. All of these subjects are compulsory and examinable, according to a Tanzania Ministry of Education official. Nonetheless, a content analysis conducted in 2008-9 on the status and place of sexuality education in the national school policy and curriculum in Tanzania concluded that the amount of sexuality education being taught is very limited and inconsistent. ${ }^{85}$ Many elements are only taught at the secondary level (although many students do not transition from primary to secondary), and the curriculum is only focused on knowledge, neglecting elements such as relationship and negotiation skills. ${ }^{86}$

In 2013, the Tanzania Institute of Education carried out an assessment of the provision and delivery of sexuality education. The assessment demonstrated that young people were not being adequately prepared for their sexual lives. A 2014 study ${ }^{87}$ corroborated these findings, indicating that:

[A] though sexuality education seems to be integrated in subjects, pupils' source of sexuality knowledge seem to be not from schools' teaching and learning but rather other sources out of schools. ... [T] here was evidence of inadequate training for teachers on how to teach and handle sexuality classes in primary schools.

Furthermore, pupils face difficulties in learning sexuality topics due to different factors such as cultural barriers, religious beliefs and personal background, teachers with relevant teaching skills and learning facilities.

In response to the 2013 findings of the Tanzania Institute of Education, UNESCO supported a review of the CSE curriculum which culminated in the development of draft guides for the "Integration of sexual and reproductive health, HIV \& AIDS and life skills components in education curriculum." The guides, 88 however, outline broad guidelines and not detailed curriculum. A review of the current guides shows that important components of CSE are contained in these guides, including contraception and accessing family planning services. The qualitative data collected in Tanzania, however, reveal a disconnect between what a curriculum may contain, and the information that teachers deliver. The following quotes from teachers and students highlight the vagueness with which CSE seems to be delivered: 
We tell them these things [condoms] are there. When you get to that stage, you will know more about them ... They have a lot of imagination, but we teach them to postpone sex (FGD with Teachers).

Let them read on their own [about condoms], but we teach according to the syllabus and it stops somewhere, and we cannot go beyond [that]. ... What they learn from the TV is at home, but not at school. That is the parents' responsibility. They should have rules at home; at school, we are doing our best (FGD with Teachers).

They are also taught about condoms, although condoms are not promoted in school (Key Informant Interview).

Narratives of teachers and students alike underscore the issue of the mistiming of curriculum delivery, given the low transitions rates of girls from primary to secondary school. These narratives also hint at the vagueness of curriculum content delivery in regard to pregnancy prevention:

Contraception is taught in Form 3 [secondary school] as part of family planning. It is also taught in Standards 6 and 7 [primary school]. These [pupils] are 12 or 13 years. They are just introduced to it, but no details are given. They are taught how to behave and how to take care of themselves (FGD with Teachers).

We are first taught about pregnancy in Form 1 ... In primary [school], it is there, but it is not well explained because we are at a young age and are not getting pregnant. ... In Form 1 Biology, there is a topic [on] personal hygiene, puberty changes and how to look after ourselves ... In Form 4, we learn about reproduction and the reproductive system in males and females, structures and their function, and about family planning and the problem of getting pregnant at early ages. In English, there is a topic of the problems of early marriage; it is in Literature (FGD with Students).

Teachers and students also mentioned that non-governmental organizations (NGOs) such as the Africa Medical Research Foundation provide pregnancy prevention information, including seminars of condom use and condom demonstrations conducted outside schools. However, both students and teachers pointed out that not all students were members of the clubs through which this information is provided.

Taken together, the interview and discussion data with teachers and students suggest that the existence of curricula may not necessarily translate into proper delivery of curriculum content. Nonetheless, a CSE curriculum framework is currently in place and under implementation in Tanzania; pre- and in-service CSE and SRH training programs for primary school teachers (of Science, Civics and Personality Development and Sports) have been established and are being implemented in 6 districts; an LSE training manual for primary school teachers has been developed, with plans underway to develop a similar manual for secondary school teachers; and a third Education Sector Strategic Plan on HIV and AIDS has been developed and validated and awaits approval.

Key informants from the Ministry of Education highlighted the challenge of widely disseminating the guidelines on CSE integration in the curricular developed by the Tanzania Institute of Education. Few of 
the teachers that participated in the focus group discussion were aware of these guidelines. According to key informants, this challenge is brought about by a lack of funds.

\section{Uganda}

Uganda has integrated CSE into its new secondary school curriculum, although the latter will not be rolled out until 2017. The country has not fully integrated CSE into the primary school curriculum.

Uganda's current sexuality education program was noted as being relatively strong, with trained teachers and a program monitoring and evaluation system in place. ${ }^{89}$ However, UNESCO's review of the curricula currently in place revealed deficiencies within the two main, current curricula: the "Life Planning Skills for Primary and Secondary" (2009) and the "Adolescent Sexual Reproductive Health/Life Planning Skills O-Level Curriculum Series" (2009). ${ }^{90}$ The O-level Curriculum Series is based upon different curricula integrated into various subjects (English, Biology, Geography, Islamic Religious Education, and Christian Religious Education), which all have their syllabus and respective curriculum. The "Life Planning Skills for Primary and Secondary" curriculum is observed to be lacking in areas concerning sexuality and negotiation skills, and self-efficacy. This curriculum is also noted to contain value judgments about sex and contraception presented as facts. The O-level curriculum series also contains some misleading information, judgmental views presented as facts, and a number of misrepresentations. Condoms are presented negatively, and, in some instances, inaccurately. Within this curriculum series, Intrauterine Devices (IUDs) are stated to cause cancer, and condoms are said to be associated with promiscuity. The Islamic religious education curriculum is the only sub-curriculum within the O-level series that teaches about proper condom use and contraceptives in a neutral manner.

FGDs with students and teachers suggest that the disconnect found in Tanzania between curriculum content and delivery is also an issue in Uganda. The lack of clarity around the comprehensiveness of pregnancy prevention messages was also observed:

[It] is mostly in biology and CRE (Christian Religious Education) ... In Biology, there is a topic on reproduction, STIs, menstruation, reproductive organs, how they function, etc. ... In CRE, we learnt about sex differences in men and woman and how to avoid early pregnancy, courtship, marriage and the dangers of early marriage ... changes in adolescence and the problems we face, and the role of the media (FGD with Students).

We talk about pregnancy in Biology and CRE - that is where the topics relating to pregnancy appear. But we also talk about it when we are counselling the students. We have sessions with the different classes where we discuss these issues (FGD with Teachers).

With condoms, we stop at condom education because that is the official policy. We cannot promote condoms in schools (FGD with Teachers).

While it will not be rolled out until 2017, Uganda has overhauled its curricula for secondary schools by merging CSE and LSE into one curriculum, dubbed 'Life Education.' A key informant interviewee representing the National Curriculum Development Centre explained that Life Education covers 
personal, social, health, and physical education. Designed to help students live an active lifestyle and understand the concepts of personal development (including sexual health), the course will inculcate in learners a sense of appreciation and responsibility for their lives, the environment they live in, and the lives of others. Life Education will be a compulsory, examinable course taught to all lower secondary school students for one 40-minute period per week. This is a positive development, from the perspective of key informants drawn from the Ministry of Education. As one of them explained:

Initially, this was a 'no-go' area, but now, it has been integrated into the national secondary school curriculum, so we are progressing. We are going into a serious campaign in order to address the resistance from teachers who will have to teach it because it will be examinable. We believe that because it is examinable, it will be taught correctly.

The use of the new curriculum will be facilitated by the development of teaching and learning aids, as well as by teacher orientation. With support from UNFPA, sample aids have been developed and piloted in schools. Among the teaching aids developed is a training manual for CRE and Physical Education teachers in particular, who, according to key informants, are best-placed to teach Life Education, given their comparatively lighter workload.

A key informant noted indications of resistance to the new curriculum among some teachers, religious leaders, and parents who have heard about Life Education. An official interviewed in the Ministry of Education explained that:

People have not yet understood what sexuality education means. It took me time to understand it myself, but what they hear is just the 'sex' part, and their immediate reaction is, 'What are you trying to teach children?' They need to be sensitized so that they can appreciate what is entailed.

From a review of the pregnancy prevention topics covered in the Life Education curriculum, it is clear that pregnancy prevention will be discussed, but how comprehensively these discussions will be seem to be left to the teacher's discretion. For instance, while students will be expected to 'explain how pregnancy can be prevented,' or to 'understand ways of reducing unintended pregnancy' by the end of the course, the information they will be provided with in order to offer these explanations (or to enhance their understanding) is not outlined. Yet, a new draft National School Health Policy that provides reentry procedures also states that learners shall be provided with information on contraceptives (including condoms) and ways to access such services. ${ }^{91}$

At the primary school level (where CSE is yet to be fully integrated), limited programmatic efforts intended for young people in Upper Primary school have been observed, according to a recent, indepth evaluation of LSE and CSE in the country. ${ }^{92}$ Conducted by the Ministry of Education and Sport with funding from UNESCO, the evaluation found that CSE is offered through NGO club activities, such as Straight Talk. While many NGOs and development partners support different projects that provide both LSE and CSE to primary school learners, the evaluation noted extensive variation in the coverage, duration, and targeted beneficiaries of these initiatives. In the words of a teacher: 'While all these organizations are all addressing sexuality education, they are not coordinated. Each comes and does 
their own thing ... Not all students attend some of these seminars because not all are members of these clubs.'

\section{Zambia}

Zambia has integrated CSE into its primary and secondary school curricula and introduced a revised CSE framework in 2013. Prior to this, UNESCO's 10-country review found that the country's LSE curricula were lacking on content relating to sexuality education and pregnancy prevention. In particular, the report notes there was sparse information on sexuality and sexual behaviours, and missing sections on condoms and contraceptive methods. ${ }^{93}$ Since then, the Zambian Ministry of Education, Science, Vocational Training and Early Education Comprehensive Sexuality Education framework has emphasized that pregnancy prevention topics in the CSE curriculum should include knowledge covering abstinence approaches and condom and contraceptive education. ${ }^{94}$ While the bulk of this information does not appear in the curriculum until the secondary levels, Zambia's revised CSE framework is strong in regards to condoms and multiple types of contraceptives are listed. ${ }^{95}$ Further, the framework is more explicit as to what should be taught. For example, multiple methods of contraception are listed and detailed steps for putting on a condom are included. ${ }^{96}$

Despite these marked improvements, there are noticeable misalignments and gaps in the new CSE framework between stated goals in regard to pregnancy prevention, areas of focus to attain these goals, and expected behavioural outcomes. For example, one of the framework's stated goals is to prevent teenage pregnancy among girls in and out of school. To foster this prevention, areas of focus such as 'methods of protection' and 'reducing perceptions of peer norms about having unprotected sex' are included. The expected outcome from focusing on these areas, however, are either not indicated, or are unrelated to the actual use of protection/contraception to meet the goal of preventing teenage pregnancy. The only exception is for out-of-school girls, for whom expected behavioural outcomes include the correct and consistent use of contraception. On the other hand, the expected behavioural outcome for girls in school is abstinence or delayed sexual debut. In explaining these gaps, key informants from the Curriculum Development Centre indicated that in developing the new CSE framework and curriculum, sensitivity to the local context and age-appropriateness were key issues that came into play. FGDs with parents provide further insight:

Early pregnancy is a problem in this country, but it is not in our culture to talk to children about relationships. In the past, grandparents sometimes talked to young people about these things, but it is difficult for a parent. Mothers try to talk to their daughters, but fathers are very busy looking for money (FGD with Parents).

You said the CSE curriculum is starting in Grade 5, but that it too early for children aged 11 years to learn about relationships. We even discourage such discussions at home for the older children. In Grades 11 and 12, it is okay, but those in Grade 5 are too young (FGD with Parents).

To address these kinds of contextual issues, and to support the roll-out of the new curriculum, the Ministry of Education, UNESCO, and SAFAIDS are implementing an interactive media campaign, which involves sensitizing communities about the new CSE curriculum, its content, and its importance, on radio and television. The campaign provides opportunities for listeners and viewers to ask any 
questions that they may have, and is designed to respond to resistance toward CSE by key stakeholders.

Implementation of the new CSE curriculum began in 2014 using a phased approach and starting out with Grades 5, 8, and 10. There are plans for the curriculum to be rolled out to Grades 6, 9, and 11 (in 2015), and to Grades 7 and 12 (in 2016). There are also intentions to introduce CSE in pre-service and in-service teacher training curricula. With support from UNESCO, some teachers have received orientation on the curriculum, and teaching and learning aids have been developed to support the delivery of CSE.

CSE in Zambia is currently integrated into examinable subjects or learning areas. There is optimism among key informants that this new development will motivate teachers to focus on delivering CSE content, as they would with any other examinable subject. However, information derived from the FGDs seems to suggest that teachers see the importance of CSE, and its role in helping to prevent early and unintended pregnancy. As one teacher intimated:

We have been preaching abstinence for a long time, but the problem of early pregnancy has continued. The new curriculum now also suggests condomization for those who cannot abstain. We know now that abstinence works for some, but not for all ... The book distributed by Ministry of Education and UNESCO encourages other methods in addition to abstinence, and I think that is useful and it is not encouraging promiscuity as some people think (FGD with Teachers).

As noted previously, however, the new CSE framework frames contraception as that which is to be taught to students out of school, and not to those in school. Yet, the gap left by such an approach is exemplified in the words of students in Zambia who had been exposed to the old CSE curriculum:

We only learnt about sexuality in Biology under 'reproduction,' and in RE (Religious Education), where we discussed fornication and adultery ... Most of what we know about relationships is from our friends. Other sources of sexuality information are books for teenagers and the internet (FGD with Students).

Those who will learn more about sexuality in the new curriculum are lucky because, for us, we learnt almost nothing (FGD with Students).

In the early grades (Grades 5-7), CSE content has specifically been integrated into Home Economics, Integrated Science, and Social Studies. Except for Home Economics (which is optional in Grades 8 and 9), these are all compulsory subjects at this level. In Grades 8 through 12, CSE has also been incorporated into Integrated Science. The integration of CSE into optional and compulsory subjects at higher grade levels raises questions about whether the 'dose' of CSE offered will vary according to a subject's categorization as 'optional' versus 'compulsory.' 


\section{School Environment and Pregnant Students/Adolescent Mothers}

This section of the report examines the education sector's response to early and unintended pregnancy in terms of the school environment. Specifically, issues involving stigma and discrimination toward pregnant girls and adolescent mothers, school structures to support these students, and linkages to health services are explored.

\section{Stigma and discrimination}

As previously discussed, stigmatization and discrimination against pregnant girls and adolescent mothers is a pervasive barrier to resuming education for the affected girls in all the study countries. The literature recognizes the effects of stigmatization and suggests the need for changing this discourse. ${ }^{97}$ A number of specific actions to reduce stigma and discrimination against pregnant girls and adolescent mothers have been identified. In Malawi, for instance, Save the Children implemented an intervention which involved raising awareness of the school re-entry policy among schools and communities and emphasizing the importance of readmission for pregnant learners/adolescent mothers. ${ }^{98} \mathrm{~A}$ very similar intervention is currently been carried out in Kenya by the Population Council. ${ }^{99}$ Preliminary findings from this program show that School Heads agree that stigma and discrimination from both the school environment and the community remain significant barriers for the affected girls. School Heads are also receptive to initiatives directed at boys and young men, but stress that parents also need to be engaged, and that sensitization is key to reducing stigma against pregnant learners and adolescent mothers in school.

It is plausible that there are other programs in the six countries working to prepare the school environment to receive pregnant learners/adolescent mothers. Many programs in general tend to go unnoticed due to a lack of proper documentation and dissemination. Further, the review suggests that whatever interventions have been conducted were not institutionalized by Ministries of Education.

\section{Supportive school structures}

There are limited structures to support pregnant girls and adolescent mothers. Some national policies, such as Kenya's NSHP or Uganda's draft NSHP, contain language that guides school administrators to provide special accommodations for pregnant students, such as permitting them to remain in school for as long possible (Kenya); counselling on the importance of antenatal care (Kenya); linking students to antenatal services (Uganda); and encouragement to attend youth-friendly clinics to obtain baby immunizations (Kenya). Low awareness of such policies among school officials is one potential barrier hindering the operationalization of such polices. A recent Kenya-based study, for instance, showed that a third of school principals had not heard of Kenya's National School Health Policy. 100

School-based counselling services for students is a form of support regarded by study interviewees as having potential to greatly enhance the lives of pregnant learners and adolescent mothers. In Zambia, a formative assessment of teenage pregnancy in primary schools found that more than half of the 
Guidance and Counselling teachers interviewed reported providing counselling services to pregnant learners before their maternity leave. ${ }^{101}$ However, the report also notes that no follow-up counselling services are offered to girls following school re-entry. It also indicated that a major support service provided to pregnant learners and adolescent mothers had to do with assisting them in filling in forms at the time of taking maternity leave. In addition, the assessment also found great variance in the frequency of guidance support provided by Guidance and Counselling teachers at the participating schools, and in the number of cases referred to them by other school staff.

Despite noting the potential of school-based guidance and counselling staff to enhance school-level support for pregnant learners/adolescent mothers, study interviewees also observed that guidance and counselling services require strengthening in schools. The major challenge highlighted was the lack of full time staff committed to guidance and counselling. In Uganda, a teacher responsible for Counselling and Guidance explained that:

In the school establishment, there is no position for a counsellor - there are only positions for teachers - and when you take on that role, your teaching load is not reduced; it is just additional work. For proper counselling of these students to take place, there is need for separate space where there is privacy, and there is need for time. But most of the time, there is no time. So, that needs to be considered very seriously if we are to help adolescent mothers return to school (FGD with Teachers).

Key informants from the Ministry of Education in Uganda (Department of Guidance and Counselling) seemed sympathetic to the plight of such teachers. One official talked of advocating for several years for the recruitment of school counsellors to no avail. Another had the following suggestion:

To request for a counsellor when the maximum number of teachers in primary school is seven - one per class - it is to request for the impossible. Maybe the Ministry can consider recruiting on counsellor per sub-county so that they service several schools within the sub-county (Key Informant Interview).

\section{Linkages to health services}

In the ESA commitment signed in December 2013, Ministers of Education and Health from 20 countries in the region reiterated their conviction that: 'The education and health sectors working jointly have enormous potential to promote the good health and wellbeing of all its individuals and communities and to prevent early and unintended pregnancy.' 102 The desk review found, however, that for most countries, literature is unavailable on official policy, guidelines or systems in place addressing the link between schools and health services - even when such linkages are recommended. Recent research in Kenya (where the NSHP stipulates that pregnant girls should be told the importance of antenatal care) showed that School Heads felt they did not have the extra resources to handle pregnant students (e.g., in the case of illness or sudden onset of labour) or to provide special accommodation to adolescent mothers. ${ }^{103}$ Despite these constraints, some School Heads in Kenya were making individual efforts to address these gaps - e.g., by creating nursing zones for adolescent mothers, permitting such mothers to return home during recess to nurse their babies and then providing extra tutoring, and by granting adolescent mothers permission to leave school briefly to attend family planning clinics. The 
Zambian re-entry policy also allows pregnant girls to remain in school, and stipulates that girls should be counselled and linked to antenatal services.

In the countries where the qualitative data were collected (Tanzania, Uganda, Zambia), it was evident that as a result of the ESA commitment, there were efforts to develop guidelines that would enable school-health facility linkages to be formalized and implemented.

While Tanzania does not have a school health policy, following the ESA commitment, a joint, costed country work plan has been developed between the Ministries of Education and Health that of Health. A joint committee involving both Ministries has been formed, and both Ministries are co-chairs to an ESA steering committee that has been scheduled to meet regularly to review progress on implementation of ESA commitment milestones.

Teacher and student respondents in Tanzania confirmed that there were no formal linkages between their particular school and a health facility. However, informal measures had been put in place. For example, the head teacher reported occasionally contacting a nearby health facility to request for a nurse to carry out pregnancy examinations at the school once or twice a year. During counselling sessions, Guidance and Counselling teachers also inform students to go to the health centre if they need information about sexual and reproductive health services.

In Uganda, the new School Health Policy and the School Health Strategic Plan (2015/16 to 2021/22) refer to linkages between schools and health services. For instance, the new School Health Policy envisages the following:

An approach that is multi-sectoral with comprehensive and effective linkages between the various stakeholders. The key ministries: Education and Sports, Health, Gender, Labour and Social Development, Local Government, Finance Planning and Economic Development (MOFPED), Lands, Water and Environment, need to develop multisectoral plans, define and operationalise effective linkages in respect to school health activities. This approach should be adopted at all levels: district, health sub-district, sub-county and school levels.

The implementation mandate for School Health lies with the Ministry of Education, which will serve as the lead Ministry, coordinating all other stakeholders through the multi-sectoral co-ordination approach. The Ministry of Health, on the other hand, will play a key role in providing technical support in regard to school health services, such as setting standards and assuring quality.

One of the objectives of Uganda's School Health Strategic Plan (2015/16 to 2021/22) is to accelerate 'the provision of quality health services in all educational institutions.' A number of strategies are proposed within the Plan to achieve this objective, including: increasing access to basic health services in all educational institutions; mainstreaming the management of communicable diseases such as HIV, AIDS and STIs in the sector; conducting refresher training to health workers of educational institutions 
with the existing standards of care; strengthening collaboration between educational institutions and health facility systems; and providing counselling, psychological, and social services in all schools.

In the meantime, it was evident from FGDs with teachers and students in Uganda that schools in close proximity to health facilities have at least informal arrangements with the latter. Teachers mentioned that health facility staff come to their particular school to give health talks, conduct pregnancy tests twice a year, and to distribute deworming tablets.

We are lucky we have a school nurse but she mainly handles first aid. If it is something serious, we normally rush the students to the hospital and then call their parents or guardians. We are lucky because Naguru Hospital also has the Naguru Teenage Centre, which offers youth-friendly services. So, we sometimes refer our students there (FGD with Teachers).

In Zambia, interviews with the Ministry of Education officials revealed that there is no specific School Health Policy in place, but schools are often used as venues for delivery of health services for children. A formative study conducted by USAID reported that the following school-based sexual and reproductive health services were available to learners: health talks by nurses or counsellors, referrals to local health facilities, and provision of counselling services to learners on HIV and teenage pregnancy.

In summary, the evidence suggests that the ESA commitment has lent traction to the creation (or intention to create) school-health facility linkages in the region. Furthermore, current informal practices in schools demonstrate that these linkages can be made and require enhancement to support the education sector response to early and unintended pregnancy.

\section{Education Sector Efforts to Improve Gender Equality}

There are several cultural and social similarities between all of the examined countries in regards to women's roles in society that carry over into the education system. Policies such as the provision of free primary and secondary education have helped close the gender parity gap, especially for poor families. All of the countries examined have at least some elements of gender equality and sensitivity built into their LSE curricula and have made efforts to incorporate gender sensitivity into the teacher training curricula, but much of this is vague and yet to show results. At closer inspection, some of the efforts may be counter-productive and do more to perpetuate traditional norms than to undo them, as was found in the Malawian LSE curriculum. ${ }^{104}$ Lack of teacher training and sensitization are generally cited as the underlying reasons for this issue. Teacher in-service trainings rarely include topics in the LSE curriculum that teach about gender sensitivity.

All six countries have adopted free primary education (FPE) policies in their efforts to achieve Millennium Development Goal 2. In all six countries, enrolment in the primary levels expanded rapidly after the provision of FPE. On average in the East and Southern Africa region, girls' enrolment in primary school is higher than that of boys, and this pattern continues through secondary school. ${ }^{105}$ 
Affirmative action programs have been used to help narrow this gap and improve gender equity, especially in University level programs. ${ }^{106}$ Bursary support for vulnerable girls and affirmative action policies have helped many girls continue their studies; 107 however, many girls drop out too soon to take advantage of the programs. Below are relevant gender policies and initiatives for the respective countries.

Botswana has achieved gender parity at the primary level. ${ }^{108}$ Free primary education includes ten years of schooling but is not compulsory. Botswana passed the National Policy on Women and Development in 1996 and has national gender policies that seek to review laws and practices to promote gender neutrality.

Kenya provides free primary and secondary education to all children, has bursaries for girls made available through the Constituency Development Fund, and affirmative action for girls for secondary and university education is in place to promote gender equality. ${ }^{109}$ Kenya developed a Gender Policy in Education in 2009.

Malawi introduced free primary education in 1994 and gender parity in primary school has been achieved, however the quality of education has suffered as expansion rapidly increased. ${ }^{110}$ A Gender Appropriate Curriculum Unit was established at the Malawi Institute of Education (MIE) by the MOEST to provide gender sensitivity training, ensure materials are gender neutral, and integrate gender sensitivity into the primary level curricula. 111 The UNESCO 10 country review of LSE found the LSE curriculum lacked depth and some lessons may actually further propel the gender norms they seek to undo. ${ }^{112}$ For example, the curriculum states that girls who dress provocatively share blame in provoking sexual harassment and abuse from males.

Tanzania implemented universal primary education in 1974 and made primary education compulsory for boys and girls (implemented in 1977) which helped increase enrolment levels for girls at secondary and university level institutions. ${ }^{113}$ Transition rates into secondary school remain roughly equivalent between boys and girls, however completion rates of secondary school for girls are lower. ${ }^{114}$ Tanzania has passed various legislation and policies to achieve gender equality including the National Education Act of 1978, National Higher Education Policy of 1999, and the National Education and Training Policy of 2002. ${ }^{115}$ Further, Tanzania's new constitution bans gender discrimination in all forms. Tanzania has affirmative action programs in place, especially at the University level. ${ }^{116}$ In collaboration with the Forum for African Women Educationalists, UNICEF provided technical and financial support to gender training for teachers in Tanzania using a handbook on Gender Responsive Pedagogy.

Uganda has affirmative action measures ingrained within its new constitution established in 1995.117 Uganda has also passed two policies that guide efforts towards achieving gender equality in education, the National Strategy for Girls' Education (2000) and the Gender in Education Policy (2007). ${ }^{118}$ Further, the Uganda Gender Policy (2007) works towards mainstreaming gender within education. ${ }^{119}$ The most recent draft LSE curriculum addresses gender stereotypes and sexual and gender-based violence. ${ }^{48}$ More recently, the Ministry of Education and Sports launched the National Strategy for Girls Education 
(NSGE) in Uganda (2015-2019). The design of the strategy was 'premised on the national desire to provide an implementation framework laying out strategies to achieve the goal of narrowing the gender gap in education particularly through promoting girls education as a form of affirmative action.' 120

The Strategy addresses the most pressing barriers to girls' full and equal participation in education in Uganda. The strategy also acts as a plan of action, highlighting the roles of different stakeholders in the sector in joint promotion of girls' education. It provides a national implementation framework laying out the strategies to achieve the goal of narrowing the gender gap in education. The priority areas of focus in the NSGE are effective policy implementation framework for girls' education, harmonization of education sector programs on girls' education, commitment of requisite resources to girls' education; institutionalization/routine research in the areas of girls' education and capacity enhancement, and involvement for all critical actors in girls' education. Teenage pregnancy is among the key gender issues highlighted in the NSGE on girls' education.

The Zambia Education Act 2011 provides for equal access to quality education and training for women and men as well as their retention at all levels of education. It further provides for challenging stereotypes in education and eradicating Gender Based Violence in educational institutions.

Article 31 within the Act ('Gender balance and equity in educational institutions and educational systems') is notable for its emphases on gender equity in access to, participation in, and completion of education; and gender-sensitive curricula and pedagogy in pre-service and in-service teachers' training. Article 32 of the Act ('Provision for protection against gender-based violence') contains stipulations around the development of procedures for preventing and responding to gender-based violence against employees, teachers and learners at educational institutions.

The Act reinforces the National Policy on Education of 1996, which has specific provisions aimed at eliminating factors that hinder access, progression and accomplishment of girls in schools and colleges, including early marriage. Section 19 indicates that an educational institution shall not discriminate against a learner in any manner, and Section 22(1) provides that the Minister shall ensure equal access to quality education to all learners, including poor and vulnerable children.

Limitations in this Act include the lack of specific reference to gender parity in decision making in all areas and at all levels within the sector. The act is also silent on the role of teachers, employees and administrators in bringing about the desired changes.

Zambia has affirmative action for girls to ensure transition to higher levels and tertiary education, bursary support offered to vulnerable girls, and rules and guidelines have been implemented at the school level to combat gender-based violence. ${ }^{121}$

There is no literature discussing initiatives within the education sector of the examined countries to engage boys and young men as a method of increasing gender equality. There are various elements 
within the LSE curricula that do promote gender equality; however, they are not directed solely at the male students. Every country examined is making an effort to incorporate gender sensitivity into their LSE curricula. MenEngage, a global NGO alliance, has community based projects operating in the East and Southern African region (including Uganda and Zambia) that directly target men as a means to reduce gender-based violence and promote gender equality; however, they operate independently of the education sector and the impact of these programs has not been evaluated. ${ }^{122}$ The United Nations Population Fund (UNFPA) partnered with the International Council on Management of Population Programmes in Uganda in a community-based program to engage men to improve access to family planning and SRH services. Again, this program operated independently of the education sector (although it does target boys in school); nonetheless, some best practices might be learned from this particular intervention. ${ }^{123}$

\section{Summary of Key Findings}

8. None of the six countries examined utilize a continuation policy for school re-entry (which would allow pregnant learners to remain in school for as long as they would like, and not require compulsory leave after giving birth).

9. Only three of the six countries (Botswana, Kenya, Zambia) have official, established school re-entry policies, while the remaining three countries (Malawi, Tanzania, Uganda) have school re-entry policies in draft form. The lack of official school re-entry policies in these countries presents an opportunity to begin to address some of the concerns raised by the review.

10. There is some policy confusion within some countries, with various education sector responses conflicting with one another. In Kenya, for example, while the Return to School policy implementation guidelines imply that pregnant learners should be sent home, the National School Health Policy stipulates that such learners should be allowed to remain in school for as long as possible. Coherent and comprehensive implementation guidelines are needed to complement existing school re-entry policies.

11. Despite efforts and progress in the area of curricula development, none of the countries examined currently offer comprehensive sexuality education as defined by UNESCO, and pregnancy prevention is not a central feature of the topics taught under life skills education or comprehensive sexuality education across the six countries. Where pregnancy prevention (including condoms and other contraceptives) is taught as part of comprehensive sexuality education, it is covered at the secondary school level alone. Low transition rates into secondary school in the study countries preclude many adolescents from the benefits of comprehensive sexuality education.

12. Programs in the six countries working to prepare school environments to receive pregnant learners/adolescent mothers were difficult to locate. This is likely due to a lack of proper documentation and dissemination of this issue. Further, the review suggests that such interventions do not end up being institutionalized by Ministries of Education. There are limited school-level structures to support adolescent mothers (such as childcare, nursing zones within schools, or financial support). 
13. Literature could not be found on official policy, guidelines, or systems in place addressing the link between schools and health services, although a few policies encourage such linkages for the benefit of pregnant learners/adolescent mothers. This suggests that such school-health facility linkages are weak.

14. All of the countries examined have at least some elements of gender equality and sensitivity built into their life skills education curricula and have made efforts to incorporate gender sensitivity into the teacher training curricula..

\section{Conclusion}

The existence of national policies and guidelines (whether in official or draft form) to promote education sector responses to early/unintended pregnancy demonstrates the commitment of countries to respond to this critical issue. Nonetheless, the gaps and inconsistencies outlined above arguably constitute a violation of pregnant learners'/adolescent mothers' rights to education, if left unaddressed. As recently as 2013, Education Ministers from across the East and Southern Africa region also confirmed their commitment to addressing early/unintended pregnancy in schools. This commitment notes the high rates of early and unintended pregnancy in the region; the low transition rates between primary and secondary school and the lack of exposure to comprehensive sexuality education as a result; gender inequality concerns in the region exacerbated by child marriage and other cultural norms that put girls in a disadvantaged position; the need for adolescents to have access to comprehensive sexual and reproductive health services, including contraception and safe abortion; the need for more investment in comprehensive sexuality education programs; and the necessity of a stronger research agenda in the region to enhance school-based programming, including the provision of condoms and other contraceptives in schools. In conclusion, while commitment from key stakeholders does not appear to be lacking, findings from this review suggest that countries in the East and Southern Africa region would benefit from intensive support to address the gaps identified.

\section{Recommendations}

o Regional bodies mandated to promote regional collaboration in education should review these national variations and facilitate harmonization, consolidation, and adherence to appropriate policies and guidelines on school re-entry. As part of this effort, prototype guidance documents (for education sector responses) that can be adapted by Ministries of Education should be developed.

o Prototype guidance documents for education sector responses should be widely popularized among education and health sector stakeholders (including integration into training curricula), and among the general public, to enhance awareness of what responses ought to be, and of who is responsible for implementing them. As part of this process, LSE and CSE curricula should be expanded to include comprehensive information on pregnancy prevention, with stipulations for this information to be provided as early as in upper primary levels to reduce unintended pregnancy, unsafe abortion and school dropout. 
o Regional bodies mandated to promote regional collaboration in education and health should convene regional workshops to promote and support linkages between Ministries of Education and Health. Specifically, linkages between schools and health services require development and strengthening. School personnel could be involved in fostering these linkages by providing information about relevant health services and referrals. Alternatively, integrated school health programs that encompass preventive and treatment services for sexual and reproductive health for students in school could be developed and tested.

o Promising programs to support school re-entry should be identified, assessed, and consolidated with a view to institutionalizing and scaling up what works in the region. 


\section{References}

1 UNFPA. 2013. Adolescent pregnancy: A review of the evidence. New York: UNFPA.

2 WHO. 2011. Early marriages, adolescent and young pregnancies. Report by the Secretariat. Available at: http://apps.who.int/gb/ebwha/pdf files/WHA65/A65 13-en.pdf. [Accessed on August 8, 2014].

${ }^{3}$ Shah I and Ahman E. 2004. Age patterns of unsafe abortion in developing country regions. Reproductive Health Matters 12 (suppl. 24): 9-17.

${ }^{4}$ Republic of Kenya. 2013. Incidence and complications of unsafe abortion in Kenya: Key findings from a national study. Nairobi: Republic of Kenya/Ministry of Health; Levandowski BA, Pearson E, Lunguzi J and Katengeza HR. 2012. Reproductive health characteristics of young Malawian women seeking post-abortion care. African Journal of Reproductive Health 16(2):253-261; Rasch V and Kipingili R. 2009. Unsafe abortion in urban and rural Tanzania: method, provider and consequences. Tropical Medicine \& International Health 14(9):1128-1133; Mirembe FM. 1996. A situation analysis of induced abortions in Uganda. African Journal of Fertility, Sexuality and Reproductive Health 1(1):79-80); Guttmacher Institute. 2009. Unsafe abortion in Zambia. New York: Guttmacher Institute.

${ }^{5}$ WHO. 2015. Maternal, newborn, child and adolescent health: Adolescent pregnancy. http://www.who.int/maternal_child_adolescent/topics/maternal/adolescent_pregnancy/en/\# [Accessed on August 9, 2014].

${ }^{6}$ Molosiwa S and Bernard M. 2012. Girl-pupil dropout in secondary schools in Botswana: Influencing factors, prevalence and consequences. International Journal of Business and Social Science 3(7):266-271.

${ }^{7}$ Muganda-Onyando, R and Omondi M. 2008. Down the drain: Counting the costs of teenage pregnancy and school dropout in Kenya. Nairobi: Centre for the Study of Adolescence.

8 Undie, C., Birungi, H., Obare, F. 2015. Expanding access to secondary school education for teenage mothers in Kenya: A baseline study report. Nairobi: Population Council.

${ }^{9}$ Ministry of Education and Vocational Training [Tanzania]. 2013. Dropout due to pregnancy in mainland Tanzania: Basic education statistics in Tanzania. Dar es Salam: Ministry of Education and Vocational Training.

${ }^{10}$ Ahikire J and Madanda A. 2011. A survey on re-entry of pregnant girls in primary and secondary schools in Uganda. Kampala: FAWE.

${ }^{11}$ Ministry of Education [Zambia]. 2010. An evaluation of re-entry policy in Zambia. Lusaka: Ministry of Education.

12 UNESCO. 2013. Young People Today. Time To Act Now. Why adolescents and young people need comprehensive sexuality education and sexual reproductive health services in Eastern and Southern Africa. Paris: United Nations Educational, Scientific and Cultural Organization.

${ }^{13}$ Chilisa B. 2002. National policies on pregnancy in education systems in sub-Saharan Africa- The case of Botswana. Gender and Education. 14(1):21-25.

14 ibid.

${ }^{15}$ Molosiwa S and Moswela, B. 2012. Girl-pupil dropout in secondary schools in Botswana: Influencing factors, prevalence and consequences. International Journal of Business and Social Science. 3(7):265-271. 
${ }^{16} \mathrm{Ibid}$.

${ }^{17}$ Okwany A. NE. 2012. Schooling for pregnant girls and student mothers: Tensions and silences in re-entry policy in Kenya. The Girl Child Network; Muganda-Onyando, R and Omondi M. 2008. Down the drain: Counting the costs of teenage pregnancy and school dropout in Kenya. Nairobi: Centre for the Study of Adolescence.

${ }^{18}$ Ministry of Public Health and Sanitation, and Ministry of Education. 2009. National School Health Policy. Nairobi: Government of Kenya.

${ }_{19}$ Muganda-Onyando R and Omondi M. 2008. Down the drain: Counting the costs of teenage pregnancy and school dropout in Kenya. Nairobi: Centre for the Study of Adolescence.

$20 \mathrm{lbid}$.

${ }^{21}$ Ministry of Public Health and Sanitation, and Ministry of Education. 2009. National School Health Policy. Nairobi: Government of Kenya, p. 23.

22 Undie, C., Birungi, H., Obare, F. 2015. Expanding access to secondary school education for teenage mothers in Kenya: A baseline study report. Nairobi: Population Council.

${ }^{23}$ Ibid.

${ }^{24}$ Ministry of Public Health and Sanitation, and Ministry of Education. 2009. National School Health Policy. Nairobi: Government of Kenya, pp. 23-24.

25 Undie, C., Mackenzie, I., Birungi, H. 2015. Expanding access to secondary school education for teenage mothers in Kenya: A policy dialogue report. Nairobi: Population Council.

${ }^{26}$ Sulo P, Nyang'au T, Chang'ach JK. 2014. Barriers to effective parental participation in teenage mothers' education in mixed day secondary schools: A case of Wareng' District, Uasin Gishu County, Kenya. Journal of Emerging Trends in Education Research and Policy Studies (JETERAPS). 5(2):133 - 139.

${ }^{27}$ Achoka JS and Njeru FM. 2012. De-Stigmatizing teenage motherhood: Towards achievement of Universal Basic Education in Kenya. Journal of Emerging Trends in Education Research and Policy Studies 3 (6):887 892.

28 Undie, C., Birungi, H., Obare, F. 2015. Expanding access to secondary school education for teenage mothers in Kenya: A baseline study report. Nairobi: Population Council.

29 Undie, C., Mackenzie, I., Birungi, H. 2015. Expanding access to secondary school education for teenage mothers in Kenya: A policy dialogue report. Nairobi: Population Council.

${ }^{30}$ Okwany A. and Ngutuku E. 2012. Schooling for pregnant girls and student mothers: Tensions and silences in re-entry policy in Kenya. Nairobi: The Girl Child Network; 2012; Wanyama EGA and Simatwa EMW. 2011. Prospects and challenges in the implementation of re-entry policy of girls in secondary schools in Kenya: A case study of Emuhaya District. International Research Journals 2(8):1373-1390.

${ }^{31}$ Wanyama EGA and Simatwa EMW. 2011. Prospects and challenges in the implementation of re-entry policy of girls in secondary schools in Kenya: A case study of Emuhaya District. International Research Journals 2(8):1373-1390.

32 Undie, C., Mackenzie, I., Birungi, H. 2015. Expanding access to secondary school education for teenage mothers in Kenya: A policy dialogue report. Nairobi: Population Council. 
${ }^{33}$ Sulo P, Nyang'au T, Chang'ach JK. 2014. Barriers to effective parental participation in teenage mothers' education in mixed day secondary schools: A case of Wareng' District, Uasin Gishu County, Kenya. Journal of Emerging Trends in Education Research and Policy Studies (JETERAPS). 5(2):133 - 139.

${ }^{34}$ Muganda-Onyando, R and Omondi M. 2008. Down the drain: Counting the costs of teenage pregnancy and school dropout in Kenya. Nairobi: Centre for the Study of Adolescence; Sulo P, Nyang'au T, Chang'ach JK. 2014. Barriers to effective parental participation in teenage mothers' education in mixed day secondary schools: A case of Wareng' District, Uasin Gishu County, Kenya. Journal of Emerging Trends in Education Research and Policy Studies (JETERAPS). 5(2):133 - 139; Achoka JS and Njeru FM. 2012. De-stigmatizing teenage motherhood: Towards achievement of Universal Basic Education in Kenya. Journal of Emerging Trends in Education Research and Policy Studies 3 (6):887 - 892.

${ }^{35}$ Wanyama EGA and Simatwa EMW. 2011. Prospects and challenges in the implementation of re-entry policy of girls in secondary schools in Kenya: A case study of Emuhaya District. International Research Journals 2(8):1373-1390.

36 Undie, C., Birungi, H., Obare, F. 2015. Expanding access to secondary school education for teenage mothers in Kenya: A baseline study report. Nairobi: Population Council.

${ }^{37}$ Ministry of Education. Revised readmission policy procedures. Malawi: Government of Malawi.

${ }^{38}$ Ministry of Education. Revised readmission policy procedures. Malawi: Government of Malawi; Yates C. 2008. Keeping children in school: A review of open education policies in Lesotho and Malawi. London, UK: Institute of Education, University of London.

${ }^{39}$ Streuli N, Moleni, C.M. 2008. Education and HIV and AIDS in Malawi: The role of open, distance and flexible learning. London, UK: Institute of Education, University of London; 2008.

40 Yates C. 2008. Keeping children in school: A review of open education policies in Lesotho and Malawi. London, UK: Institute of Education, University of London.

$41 \mathrm{lbid}$.

${ }^{42}$ Center for Reproductive Rights. 2013. Forced Out, Mandatory Pregnancy Testing and the Expulsion of Pregnant Students in Tanzanian Schools. Center for Reproductive Rights.

43 Ibid.

44 Ibid.

${ }^{45}$ Nyirenda M. Girls' re-entry policy can support education for all. 2012. http://www.ippmedia.com/frontend/index.php?l=39151; Yates C. 2008. Keeping children in school: A review of open education policies in Lesotho and Malawi. London, UK: Institute of Education, University of London.

${ }^{46}$ Carrington D. 2011. Why women's education in Tanzania is critical for slowing population growth. Global Development. http://www.theguardian.com/global-development/2011/oct/24/women-education-tanzaniapopulation; Yates C. 2008. Keeping children in school: A review of open education policies in Lesotho and Malawi. London, UK: Institute of Education, University of London.

${ }^{47}$ Center for Reproductive Rights. 2013. Forced Out, Mandatory Pregnancy Testing and the Expulsion of Pregnant Students in Tanzanian Schools. Center for Reproductive Rights. 
${ }^{48}$ Republic of Uganda: Ministry of Education and Sports MoH, MWSES Consult. Finalisation of the National School Health Policy and Health Strategic Plan 2011 - 2015, National School Health Policy - Draft. Kampala, Uganda: Republic of Uganda: Ministry of Education and Sports; Ministry of Health.

${ }^{49}$ Ahikire JA, Madanda, A. 2011. A Survey on Re-Entry of Pregnant Girls in Primary and Secondary Schools in Uganda. FAWE Uganda; Republic of Uganda: Ministry of Education and Sports MoH, MWSES Consult, Finalisation of the National School Health Policy and Health Strategic Plan 2011 - 2015, National School Health Policy - Draft. Kampala, Uganda: Republic of Uganda: Ministry of Education and Sports; Ministry of Health.

${ }^{50}$ Ahikire JA, Madanda, A. A Survey on Re-Entry of Pregnant Girls in Primary and Secondary Schools in Uganda. FAWE Uganda; 2011.

51 lbid.

52 Mwansa A. 2011. Re-entry to School after Giving Birth: An Evaluation of the Process used to Design and Implement Policy in Zambia. The Institute of Education, University of London, UK; Consortium for Research on Educational Access, Transitions and Equity.

${ }^{53}$ Zambia Ministry of Education, Science, Vocational Training and Early Education, Zambia Educational Statistical Bulletin 2012.

${ }^{54}$ Ministry of Education, FAWEZA, and UNICEF (for the Go Girls! Campaign). 2004. Guidelines for the Re-Entry Policy. Lusaka, Zambia.

55 ibid.

56 ibid.

57 Ibid.

${ }^{58}$ Mwansa A. Re-entry to School after Giving Birth: An Evaluation of the Process used to Design and Implement Policy in Zambia. 2011. The Institute of Education, University of London, UK; Consortium for Research on Educational Access, Transitions and Equity.

$59 \mathrm{lbid}$

60 GenderLinks.org. Zambia: Re-entry policy puts girls back in school. 2011; http://www.genderlinks.org.za/article/zambia-re-entry-policy-puts-girls-back-in-school-2011-09-30.

${ }^{61}$ Mwansa A. Re-entry to School after Giving Birth: An Evaluation of the Process used to Design and Implement Policy in Zambia. 2011. The Institute of Education, University of London, UK; Consortium for Research on Educational Access, Transitions and Equity.

62 Zambia Ministry of Education, Science, Vocational Training and Early Education. 2012. A review of the implementation of the Re-entry Policy. Lusaka: Government of Zambia.

63 UNESCO. 2013. Young People Today. Time To Act Now. Why adolescents and young people need comprehensive sexuality education and sexual reproductive health services in Eastern and Southern Africa. United Nations Educational, Scientific and Cultural Organization, p. 21.

64 UNESCO. 2009. International Technical Guidance on Sexuality Education: An evidence-informed approach for schools teachers and health educators. Paris, France: United Nations Educational, Scientific and Cultural Organization, p.2. 
${ }^{65}$ Network for Adolescents and Youth of Africa (NAYA). 2011. Rapid assessment on the Effectiveness of Life Skills Education in Kenya. Nairobi, Kenya: Network for Adolescents and Youth of Africa.

66 UNESCO. 2012. Sexuality Education: A ten-country review of school curricula in East and Southern Africa. United Nations Educational, Scientific, and Cultural Organization; UNESCO. 2013. Young People Today. Time To Act Now. Why adolescents and young people need comprehensive sexuality education and sexual reproductive health services in Eastern and Southern Africa. United Nations Educational, Scientific and Cultural Organization.

${ }^{67}$ UNESCO. 2012. Sexuality Education: A ten-country review of school curricula in East and Southern Africa. United Nations Educational, Scientific, and Cultural Organization.

$68 \mathrm{lbid}$.

69 Network for Adolescents and Youth of Africa (NAYA). 2011. Rapid assessment on the Effectiveness of Life Skills Education in Kenya. Nairobi, Kenya: Network for Adolescents and Youth of Africa.

${ }^{70}$ Republic of Botswana. 2012. Draft: The National School Health Policy. In: Department of Public Health HPaED, ed2012; Republic of Botswana. Draft: The National School Health Programme, Implementation Strategy, 2012 - 2016.

${ }^{71}$ Republic of Botswana. 2011. Adolescent Sexual and Reproductive Health Implementation Strategy, 2012 2016.

72 Mugambi MM, Muthui, R.K. 2013. Influence of Structural Context on Implementation of Secondary School Life Skills Curriculum in Kajiado County, Kenya. International Journal of Education and Research. 1(3).

${ }^{73}$ Network for Adolescents and Youth of Africa (NAYA). 2011. Rapid assessment on the Effectiveness of Life Skills Education in Kenya. Nairobi, Kenya: Network for Adolescents and Youth of Africa.

74 UNESCO. 2012. Sexuality Education: A ten-country review of school curricula in East and Southern Africa. United Nations Educational, Scientific, and Cultural Organization.

${ }^{75}$ Mugambi MM, Muthui, R.K.2013. Influence of Structural Context on Implementation of Secondary School Life Skills Curriculum in Kajiado County, Kenya. International Journal of Education and Research 1(3).

76 USAID. 2012. Making Comprehensive Sexuality Education Available at a National Scale: A Case Study About Tailoring International Guidance for Kenya. United States Agency for International Development.

${ }^{77}$ Centre for Social Research. 2011. Life Skills Education and Reproductive Health Education, Preliminary Findings from the Non-biomedical Interventions into HIV and AIDS. Zomba, Malawi: Centre for Social Research.

${ }^{78}$ UNESCO. 2012. Sexuality Education: A ten-country review of school curricula in East and Southern Africa. United Nations Educational, Scientific, and Cultural Organization.

79 UNESCO. 2013. Young People Today. Time To Act Now. Why adolescents and young people need comprehensive sexuality education and sexual reproductive health services in Eastern and Southern Africa. United Nations Educational, Scientific and Cultural Organization.

80 UNESCO. 2012. Sexuality Education: A ten-country review of school curricula in East and Southern Africa. United Nations Educational, Scientific, and Cultural Organization. 
${ }^{81}$ Centre for Social Research. 2011. Life Skills Education and Reproductive Health Education, Preliminary Findings from the Non-biomedical Interventions into HIV and AIDS. Zomba, Malawi: Centre for Social Research.

82 ibid.

83 Ibid.

84 UNESCO. Sexuality Education: A ten-country review of school curricula in East and Southern Africa. United Nations Educational, Scientific, and Cultural Organization; 2012.

${ }^{85}$ Mkumbo KA. 2009. Content analysis of the status and place of sexuality education in the national school policy and curriculum in Tanzania. Educational Research and Review. 4(12):616-625.

86 Ibid.

${ }^{87}$ Bilinga, Magreth, and Nkuba Mabula. "Teaching Sexuality Education in Primary Schools in Tanzania:

Challenges and Implications." Journal of Education and Practice 5.27 (2014): 21-30.

${ }^{88}$ Tanzania Institute of Education U. 2013. Guide for the Integration of Sexual and Reproductive Health, HIV \& AIDS and Life Skills Components of the Secondary Education Curricula, Form I-IV. In: Tanzania Institute of Education URoT, ed2013.

89 UNESCO. 2012. Sexuality Education: A ten-country review of school curricula in East and Southern Africa. United Nations Educational, Scientific, and Cultural Organization.

90 ibid.

${ }^{91}$ Republic of Uganda: Ministry of Education and Sports MoH, MWSES Consult. Finalisation of the National School Health Policy and Health Strategic Plan 2011 - 2015, National School Health Policy - Draft. Kampala, Uganda: Republic of Uganda: Ministry of Education and Sports; Ministry of Health.

${ }^{92}$ Ministry of Education and Sport. 2014. In-Depth evaluation of Life Skills and Sexuality Education in upper primary schools in Uganda.

${ }^{93}$ UNESCO. 2012. Sexuality Education: A ten-country review of school curricula in East and Southern Africa. United Nations Educational, Scientific, and Cultural Organization.

${ }^{94}$ Curriculum Development Centre. 2013. Comprehensive Sexuality Education Framework (Grades 5-12). Lusaka, Zambia: Republic of Zambia, Ministry of Education, Science, Vocational Training and Early Education. 95 ibid.

96 Ibid.

${ }^{97}$ Achoka JS and Njeru FM. 2012. De-Stigmatizing teenage motherhood: Towards achievement of Universal Basic Education in Kenya. Journal of Emerging Trends in Education Research and Policy Studies 3 (6):887 892.

${ }^{98}$ Save the Children (n.d.) Reaching out to teen mothers in Malawi https://www.k4health.org/sites/default/files/Reaching\%200ut\%20to\%20Teen\%20Mothers\%20in\%20Malawi 0.pd f.

${ }^{99}$ Undie C, Mackenzie I, Birungi H. 2015. Expanding access to secondary school education for teenage mothers in Kenya: A policy dialogue report. Nairobi: Population Council. 
100 Undie, C., Birungi, H., Obare, F. 2015. Expanding access to secondary school education for teenage mothers in Kenya: A baseline study report. Nairobi: Population Council.

101 Mwansa. C. Audrey and Jacob W. James. 2015. A Formative Assessment of Teenage Pregnancy in Zambian Primary Schools: Eastern, Luapula and North-Western Provinces.

102 Ministerial Commitment on comprehensive sexuality education and sexual and reproductive health services for adolescents and young people in Eastern and Southern African, December 7, 2013, p. 1.

http://www.unesco.org/new/fileadmin/MULTIMEDIA/HQ/HIV-

AIDS/pdf/ESACommitmentFINALAffirmedon7thDecember.pdf.

103 Undie C, Mackenzie I, Birungi H. 2015. Expanding access to secondary school education for teenage mothers in Kenya: A policy dialogue report. Nairobi: Population Council.

104 UNESCO. 2012. Sexuality Education: A ten-country review of school curricula in East and Southern Africa. United Nations Educational, Scientific, and Cultural Organization.

105 UNICEF Eastern and Southern Africa Office (n.d.). Gender and Education.

http://www.unicef.org/esaro/7310 Gender and education.html.

${ }^{106}$ Onsongo J. 2009. Affirmative action, gender equity and university admissions - Kenya, Uganda and Tanzania. London Review of Education 7(1):71 - 81.

107 Save the Children (n.d.) Reaching out to teen mothers in Malawi

https://www.k4health.org/sites/default/files/Reaching\%200ut\%20to\%20Teen\%20Mothers\%20in\%20Malawi 0.pd f.

108 United Nations Development Programme. Promote gender equality and empower women. 2012; http://www.bw.undp.org/content/botswana/en/home/mdgoverview/overview/mdg3/. Accessed 9/27/14.

109 Sulo P, Nyang'au T, Chang'ach JK, 2014. Barriers to Effective Parental Participation in Teenage Mothers' Education in Mixed Day Secondary Schools: A Case of Wareng' District, Uasin Gishu County, Kenya. Journal of Emerging Trends in Education Research and Policy Studies (JETERAPS). 5(2):133 - 139; Onsongo J. 2009. Affirmative action, gender equity and university admissions - Kenya, Uganda and Tanzania. London Review of Education. 7(1):71 - 81.

${ }^{110}$ Bisika T, Ntata P, Konyani S. 2009. Gender-Violence and education in Malawi: a study of violence against girls as an obstruction to universal primary education. Journal of Gender Studies 18(3):287-294; Chisamya G, DeJaeghere J, Kendall N, Khan MA. 2012. Gender and Education for All: Progress and Problems in Achieving Gender Equity. International Journal of Educational Development.21:743 - 755.

${ }^{111}$ Banda DM. 2004. Gender Sensitive Educational Policy and Practice: The Case of Malawi. Prospects. 39(1):71 $-84$.

112 UNESCO. 2012. Sexuality Education: A ten-country review of school curricula in East and Southern Africa. United Nations Educational, Scientific, and Cultural Organization.

${ }^{113}$ Lihamba A, Mwaipopo R, Shule L. 2006. The Challenges of Affirmative Action in Tanzanian Higher Education Institutions: A Case Study of the University of Dar es Salaam, Tanzania. Women's International Forum. 29:581 591. 
114 Okkolin M-A, Lehtomäki E, Bhalalusesa E. 2010. The Successful Education Sector Development in Tanzania - Comment on Gender Balance and Inclusive Education. Gender and Education. 22(1):63 - 71.

115 Onsongo J. 2009. Affirmative action, gender equity and university admissions - Kenya, Uganda and Tanzania. London Review of Education. 7(1):71 - 81.

116 Onsongo J. 2009. Affirmative action, gender equity and university admissions - Kenya, Uganda and Tanzania. London Review of Education. 7(1):71 - 81. Lihamba A, Mwaipopo R, Shule L. 2006. The Challenges of Affirmative Action in Tanzanian Higher Education Institutions: A Case Study of the University of Dar es Salaam, Tanzania. Women's International Forum. 29:581 - 591.

117 Onsongo J. 2009. Affirmative action, gender equity and university admissions - Kenya, Uganda and Tanzania. London Review of Education. 7(1):71 - 81.

118 Kagoda AM. 2011. Assessing the Effectiveness of Affirmative Action on Women's Leadership and Participation in Education Sector in Uganda. UNESCO, International Institute for Educational Planning.

119 ibid.

${ }^{120}$ Republic of Uganda (2013). Ministry of Education and Sports National Strategy for Girls' Education in Uganda (2015-2019). http://www.ungei.org/resources/files/Resource Uganda NSGE.pdf.

121 GenderLinks.org. 2011. Zambia: Re-entry policy puts girls back in school; http://www.genderlinks.org.za/article/zambia-re-entry-policy-puts-girls-back-in-school-2011-09-30.

122 MenEngage. About Us. 2014; http://menengage.orgl. Accessed 10/18/2014.

123 UNFPA and ICOMP (International Council on Management of Population Programmes). 2011. Engaging men and boys in gender equality: Vignettes from Asia and Africa;

http://asiapacific.unfpa.org/webdav/site/asiapacific/shared/Publications/2011/Engaging\%20Men\%20and\%20Boys .pdf. 